\title{
Modelling the geochemical fate and transport of wastewater-derived phosphorus in contrasting groundwater systems
}

\author{
Claudette Spiteri ${ }^{\mathrm{a}, *}$, Caroline P. Slomp ${ }^{\mathrm{a}}$, Pierre Regnier ${ }^{\mathrm{a}}$, \\ Christof Meile $^{\mathrm{b}}$, Philippe Van Cappellen ${ }^{\mathrm{a}}$ \\ ${ }^{a}$ Department of Earth Sciences-Geochemistry, Faculty of Geosciences, Utrecht University, \\ P.O. Box 80021, 3508 TA Utrecht, The Netherlands \\ ${ }^{\mathrm{b}}$ Department of Marine Sciences University of Georgia, Athens, GA 30602-3636, USA
}

Received 8 November 2005; received in revised form 27 December 2006; accepted 2 January 2007 Available online 10 January 2007

\begin{abstract}
A 1D reactive transport model (RTM) is used to obtain a mechanistic understanding of the fate of phosphorus $(\mathrm{P})$ in the saturated zone of two contrasting aquifer systems. We use the field data from two oxic, electron donor-poor, wastewater-impacted, sandy Canadian aquifers, (Cambridge and Muskoka sites) as an example of a calcareous and non-calcareous groundwater system, respectively, to validate our reaction network. After approximately 10 years of wastewater infiltration, $\mathrm{P}$ is effectively attenuated within the first $10 \mathrm{~m}$ downgradient of the source mainly through fast sorption onto calcite and $\mathrm{Fe}$ oxides. Slow, kinetic sorption contributes further to $\mathrm{P}$ removal, while precipitation of phosphate minerals (strengite, hydroxyapatite) is quantitatively unimportant in the saturated zone. Nitrogen (N) dynamics are also considered, but nitrate behaves essentially as a conservative tracer in both systems. The model-predicted advancement of the $\mathrm{P}$ plume upon continued wastewater discharge at the calcareous site is in line with field observations. Model results suggest that, upon removal of the wastewater source, the $\mathrm{P}$ plume at both sites will persist for at least 20 years, owing to desorption of $\mathrm{P}$ from aquifer solids and the slow rate of $\mathrm{P}$ mineral precipitation. Sensitivity analyses for the noncalcareous scenario (Muskoka) illustrate the importance of the sorption capacity of the aquifer solids for $\mathrm{P}$ in modulating groundwater $\mathrm{N}: \mathrm{P}$ ratios in oxic groundwater. The model simulations predict the breakthrough of groundwater with high P concentrations and low N:P ratios after 17 years at $20 \mathrm{~m}$ from the source for an aquifer with low sorption capacity $\left(<0.02 \% \mathrm{w} / \mathrm{w} \mathrm{Fe}(\mathrm{OH})_{3}\right)$. In this type of system,
\end{abstract}

* Corresponding author. Tel.: +31 30253 4968; fax: +31 302535302 .

E-mail address: c.spiteri@geo.uu.nl (C. Spiteri). 
denitrification plays a minor role in lowering the N:P ratios because it is limited by the availability of labile dissolved organic matter.

(C) 2007 Elsevier B.V. All rights reserved.

Keywords: Phosphorus; Nitrogen; N:P ratio; Groundwater; Sorption capacity; Reactive transport modelling

\section{Introduction}

Since the early 1960s, concentrations of phosphorus (P) and nitrogen $(\mathrm{N})$ in groundwater have increased worldwide as a result of the agricultural application of manure and synthetic fertilizer (Appelo and Postma, 1996), and input of wastewater (Wilhelm et al., 1994a). Although groundwater nitrate concentrations now frequently exceed the maximum permissible limits for drinking water (e.g. $10 \mathrm{mg} \mathrm{L}^{-1} \mathrm{NO}_{3}^{-} \mathrm{N}$ in the United States (Sayre, 1988)), elevated phosphate concentrations are less common as $\mathrm{P}$ is often immobilized by interactions with aquifer solids. Distinct groundwater P plumes are, therefore, mostly observed close to point sources such as septic systems (e.g. Robertson, 1995; Harman et al., 1996; Ptacek, 1998; Corbett et al., 2002). Dissolved N and P concentrations in septic effluents can be as high as 3000 and $400 \mu \mathrm{M}$, respectively, which is $2-3$ orders of magnitude higher than is typical for receiving water bodies (Weiskel and Howes, 1992).

Discharge of groundwater contaminated with P and/or N to streams, lakes (e.g. Weiskel and Howes, 1992) and coastal waters (Valiela et al., 1990; Wilhelm et al., 1994a; Slomp and Van Cappellen, 2004) can lead to a deterioration in surface water quality due to eutrophication. Depending on the N:P ratios of the groundwater and receiving surface waters, groundwater discharge may also lead to a shift in the limiting nutrient for primary production (Slomp and Van Cappellen, 2004) and contribute to the occurrence of harmful algal blooms (Valiela et al., 1990; Anderson et al., 2002). This makes it important to have a quantitative understanding of the major removal processes affecting both $\mathrm{P}$ and $\mathrm{N}$ in groundwater systems.

Most studies on nutrients in groundwater systems focus on tracking nutrient concentrations along flowpaths (Robertson et al., 1991; Harman et al., 1996; Ptacek, 1998; Corbett et al., 2002; Griggs et al., 2003). Nitrogen dynamics in groundwater are relatively well-studied. Field studies and mass balance/reactive transport modelling have shown that in some aquifers denitrification, coupled to either organic matter or pyrite oxidation, is the major removal process for groundwater N (Frind et al., 1990; Postma et al., 1991; MacQuarrie and Sudicky, 2001). Results of combined column experiments and reactive transport modelling (Isenbeck-Schröter et al., 1993; Stollenwerk, 1996) suggest that sorption processes largely control $\mathrm{P}$ retention onto aquifer solids. Most of this P is bound to Fe oxides (Robertson, 1995) and calcium carbonate (Cole et al., 1953; Bohn et al., 1985; Corbett et al., 2000), with the former generally having the highest sorption capacity (Krom and Berner, 1980; Frossard et al., 1995). This is reflected in typical adsorption coefficients for $\mathrm{P}$ on Fe oxides (goethite) that are three orders of magnitude higher than those for calcite $\left(K=3000 \mathrm{~mL} \mathrm{~g}^{-1}\right.$ and $10 \mathrm{~mL} \mathrm{~g}^{-1}$, respectively; Krom and Berner, 1980).

Sorption of $\mathrm{P}$ is generally considered to be a two-step process; an initial fast adsorption at high affinity mineral surface sites (Parfitt, 1978, 1989), followed by slow diffusion into micropores or aggregates (Barrow, 1985; Torrent et al., 1992; Slomp et al., 1998; Mikutta et al., 2006) or precipitation of metal phosphate phases (Van Riemsdijk et al., 1984). Phosphate has the ability to form a number of sparingly soluble secondary minerals of which the most common are strengite $\left(\mathrm{FePO}_{4} \cdot 2 \mathrm{H}_{2} \mathrm{O}\right)$, vivianite $\left(\mathrm{Fe}_{3}\left(\mathrm{PO}_{4}\right)_{2} \cdot 8 \mathrm{H}_{2} \mathrm{O}\right)$, variscite $\left(\mathrm{AlPO}_{4} \cdot 2 \mathrm{H}_{2} \mathrm{O}\right)$ and hydroxyapatite $\left(\mathrm{Ca}_{5}\right.$ 
$\left.\left(\mathrm{PO}_{4}\right)_{3} \mathrm{OH}\right)$ (Nriagu and Dell, 1974; Nriagu and Moore, 1984; Zanini et al., 1998; Robertson, 2003). So far, little quantitative information is available on the relative roles of fast and slow sorption and mineral precipitation in determining $\mathrm{P}$ mobility in groundwater at field sites.

In this study, we present a $1 \mathrm{D}$ reactive transport model describing $\mathrm{P}$ and $\mathrm{N}$ dynamics in groundwater systems. The model is applied to field data for two oxic septic plumes propagating in the saturated zone of two contrasting aquifers, one rich in calcite, the other in Fe oxides (Robertson et al., 1991; Robertson et al., 1998; Robertson, 2003). Given the low concentrations of dissolved $\mathrm{P}$ and associated high analytical uncertainties in the measurements, in particular in the saturated zone of the Fe oxide-rich aquifer, the aims of this modelling exercise are to capture the trends in nutrient concentrations in two contrasting aquifers using a process-oriented model, to predict their evolution in time and to assess their sensitivity to changes in $\mathrm{P}$ input. In addition, we address the role of fast and slow sorption processes in limiting $\mathrm{P}$ concentrations in groundwater, as well as the key factors controlling groundwater N:P ratios.

\section{Model description}

The biogeochemical processes that determine groundwater $\mathrm{N}$ and $\mathrm{P}$ dynamics are incorporated in the Biogeochemical Reaction Network Simulator (BRNS), a flexible modelling environment for one-dimensional simulations in groundwater, sediments and surface waters (Regnier et al., 2002, 2003; Aguilera et al., 2005). In the model, the transport and reaction of solutes are described by:

$$
\frac{\partial C_{j}}{\partial t}=-v \frac{\partial C_{j}}{\partial x}+D \frac{\partial^{2} C_{j}}{\partial x^{2}}+R_{j} \quad\left(j=1, \ldots, N_{\text {tot }}\right)
$$

where $v$ is the average linear velocity $\left(\mathrm{m} \mathrm{yr}^{-1}\right), C_{j}$ is the concentration of a solute $\left(\mathrm{mol} \mathrm{m}^{-3}\right.$ porewater), $D$ is the dispersion coefficient $\left(\mathrm{m}^{2} \mathrm{yr}^{-1}\right)$ which is equal to the product of dispersivity $\alpha_{L}(\mathrm{~m})$ and $v$, $R_{j}$ is the net rate of transformation of the solute $\left(\mathrm{mol} \mathrm{m}^{-3} \mathrm{yr}^{-1}\right)$ due to reaction, and $N_{\text {tot }}$ is the total number of species. In all our applications, $v$ and $D$ are assumed to be constant in space and time. The term $R_{j}$ can be written explicitly as the sum of all $N_{r}$ reaction rates that modify the concentration of the $j$ th species:

$$
R_{j}=\sum_{m=1}^{N_{r}} v_{m j} r_{m}
$$

where $r_{m}$ is the rate of reaction and $v_{m j}$ is the stoichiometric number of species $j$ in the reaction formula. Solids ( $\mathrm{mol} \mathrm{m}^{-3}$ total volume) are considered immobile and hence are only affected by local biogeochemical transformations. The set of coupled partial differential equations (PDEs) is solved through an implicit sequential non-iterative operator splitting approach (SNIA) which makes use of the iterative Newton Method for solving the reaction part. The latter can handle mixed kineticequilibrium reaction systems. Further details can be found in Aguilera et al. (2005).

\subsection{Main reaction network}

Our model considers 8 solids $\left(\mathrm{CaCO}_{3}, \mathrm{Ca}\left(\mathrm{PO}_{4}\right)_{3} \mathrm{OH}, \mathrm{Fe}(\mathrm{OH})_{3}, \mathrm{FePO}_{4} \cdot 2 \mathrm{H}_{2} \mathrm{O}, \mathrm{Fe}_{3}\left(\mathrm{PO}_{4}\right)_{2} \cdot 8 \mathrm{H}_{2} \mathrm{O}\right.$, $\left.\mathrm{NH}_{4(\text { ads })}, \mathrm{P}_{\text {s-fast }}, \mathrm{P}_{\text {s-slow }}\right), 15$ solutes $\left(\mathrm{Ca}^{2+}, \mathrm{CO}_{2}, \mathrm{CO}_{3}^{2-}, \mathrm{DOC}_{1}, \mathrm{DOC}_{2}, \mathrm{Fe}^{2+}, \mathrm{H}^{+}, \mathrm{HCO}_{3}^{-}, \mathrm{HPO}_{4}^{2-}\right.$, $\mathrm{H}_{2} \mathrm{PO}_{4}^{-}, \mathrm{Na}^{+}, \mathrm{NH}_{4}^{+}, \mathrm{NO}_{3}^{-}, \mathrm{O}_{2}, \mathrm{PO}_{4}^{3-}$ ) and 21 reaction pathways (Table 1). Units for solutes and 


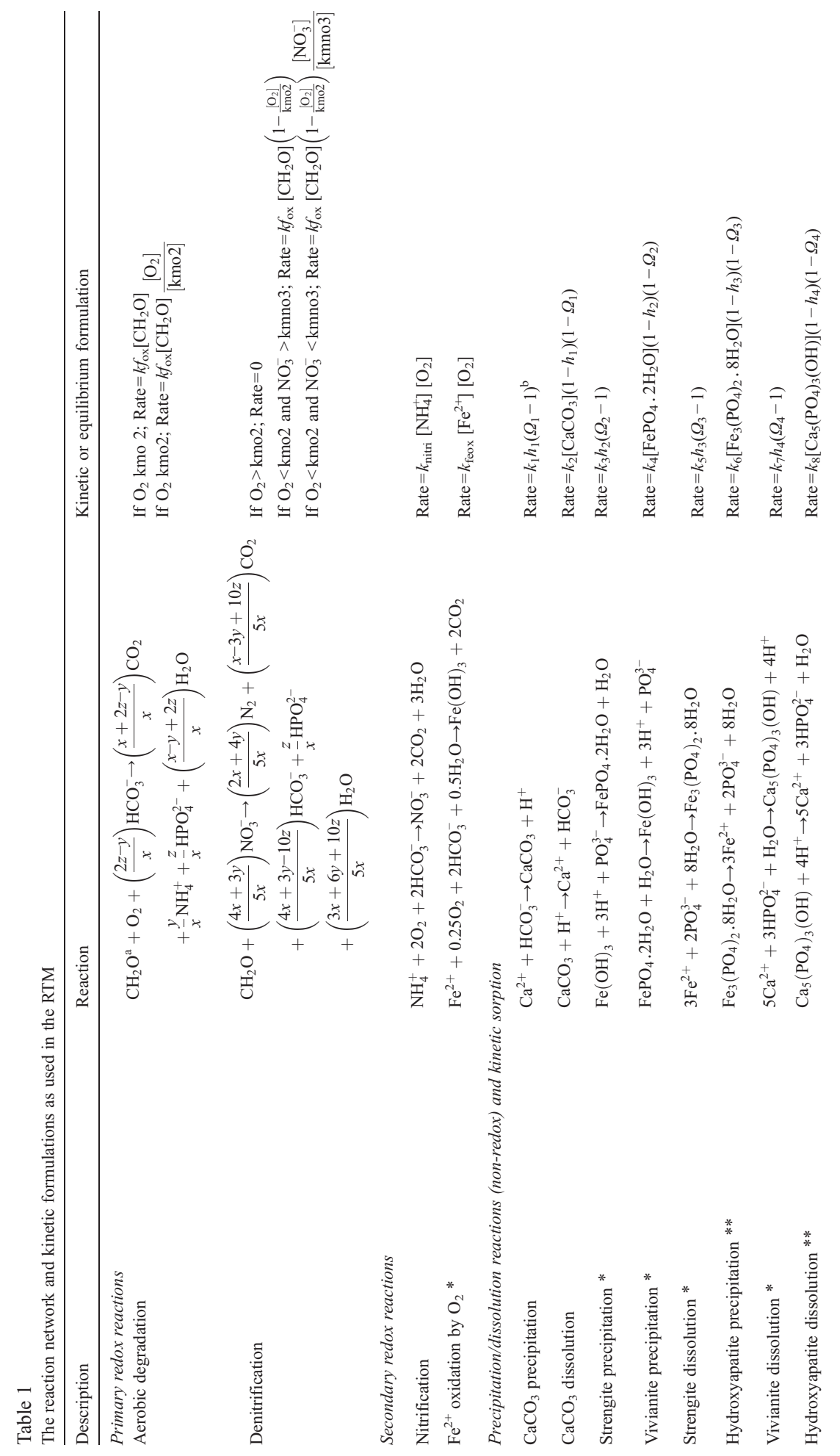



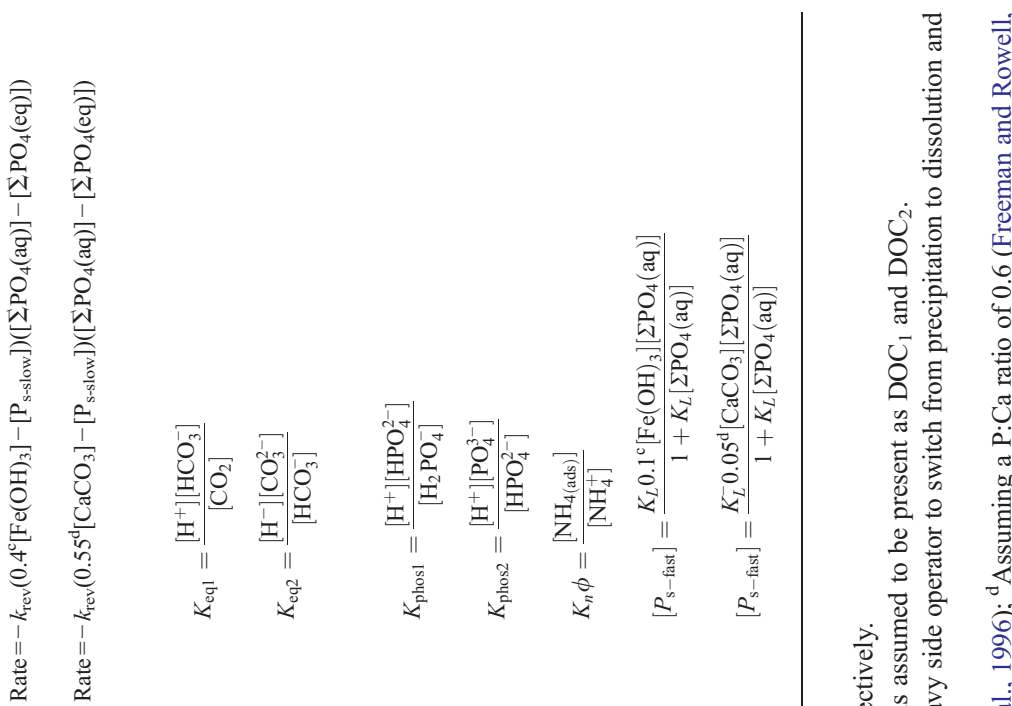

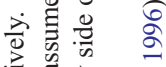

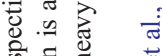

की

Сูป

$\therefore \ddot{i}$.

$\sum_{N} \frac{1}{\circ}$

i 0 .

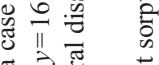

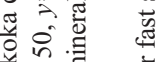

寒沓

$\frac{u}{0} \frac{0}{2}$

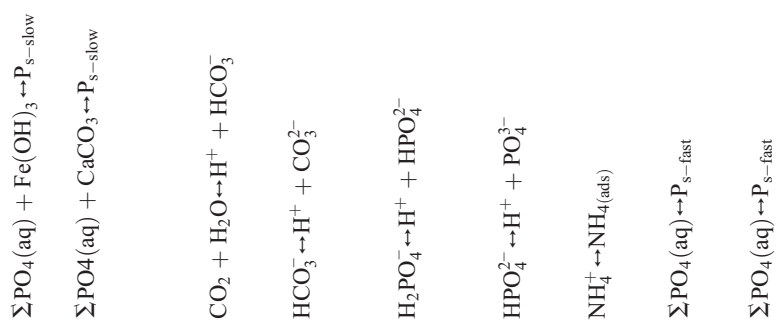

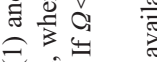

خิ

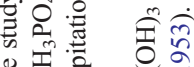

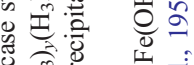

के

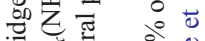

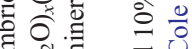

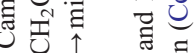

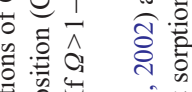

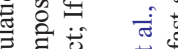

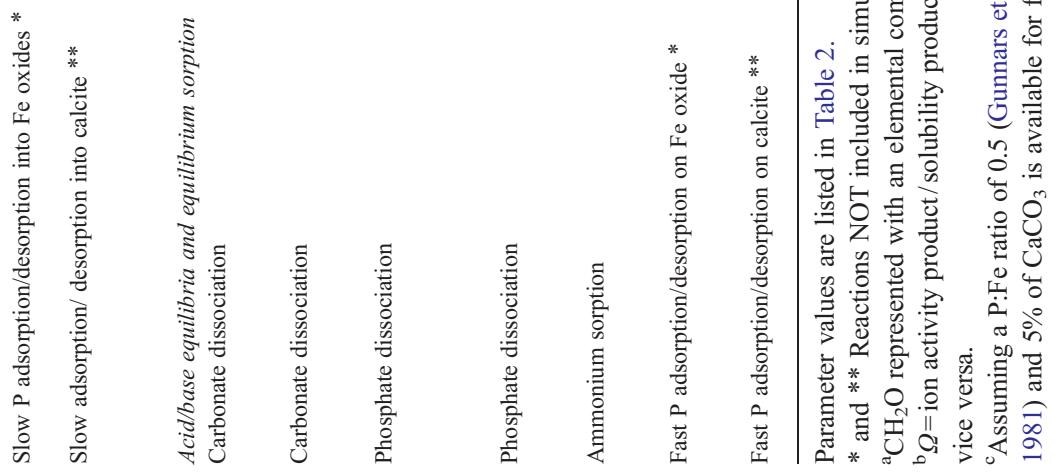


solids are denoted in $\mathrm{mM}\left(\mathrm{mmol} \mathrm{dm}^{-3}\right.$ pore volume $)$ and $\mathrm{mmol} \mathrm{dm}^{-3}\left(\mathrm{mmol} \mathrm{dm}^{-3}\right.$ total volume), respectively. The reaction network includes aerobic dissolved organic carbon (DOC) degradation, denitrification, secondary reoxidation reactions, precipitation/dissolution of calcium carbonate and $\mathrm{P}$ minerals, acid-base equilibria and reversible $\mathrm{P}$ and $\mathrm{NH}_{4}^{+}$sorption.

Mineralization of DOC is modelled using the multi-G approach (Westrich and Berner, 1984), in which the pool of degradable DOC is assumed to be composed of various types of organic matter with different reactivities. Here two fractions of DOC are assumed; a labile fraction in the sewage effluent, which percolates through the unsaturated zone and reaches the water table $\left(\mathrm{DOC}_{1}\right)$, and a less labile fraction which represents the organic matter present in groundwater under natural conditions $\left(\mathrm{DOC}_{2}\right)$. Both fractions can be degraded through aerobic degradation and denitrification. The rate laws for DOC degradation (Table 1) allow a smooth transition from aerobic degradation to denitrification. When the concentration of $\mathrm{O}_{2}$ exceeds the limiting value kmo2 (Tables 1 and 2), the rate of aerobic degradation is independent of the $\mathrm{O}_{2}$ concentration. For $\mathrm{O}_{2}$ concentrations below $\mathrm{kmo}$, the reaction is limited by $\mathrm{O}_{2}$, while denitrification is simultaneously activated. Further details on the implementation of the rate laws for organic matter degradation can be found in Van Cappellen and Wang (1996), Hunter et al. (1998) and Aguilera et al. (2005).

The $\mathrm{N}$ species included in the model are dissolved $\mathrm{NO}_{3}^{-}$and $\mathrm{NH}_{4}^{+}$, and adsorbed $\mathrm{NH}_{4}^{+}$. Nitrate is produced by nitrification and consumed by denitrification, while $\mathrm{NH}_{4}^{+}$is released by aerobic degradation and removed from solution by nitrification and adsorption (Table 1). Secondary redox reactions, such as nitrification and reoxidation of $\mathrm{Fe}^{2+}$ from wastewater effluent, are assigned bimolecular rate laws (Table 1). Ammonium sorption is described by a linear equilibrium isotherm with a constant dimensionless adsorption coefficient, $K_{n}$. The porosity $\phi$ $\left(\mathrm{dm}^{3}\right.$ pore water $\mathrm{dm}^{-3}$ total volume) is introduced in the model equations (Table 1) to account for the difference in the units of solid and solute species. Dissociation of carbonic acid is included as an equilibrium reaction. Rates of mineral precipitation and dissolution reactions depend on the degree of mineral under- or supersaturation of the groundwater (Table 1), using the formulations in Van Cappellen and Wang (1996).

\subsection{P dynamics}

Dissolved $\mathrm{P}$ in the system, $\Sigma \mathrm{PO}_{4}(\mathrm{aq})$, is distributed between three forms: $\mathrm{H}_{2} \mathrm{PO}_{4}^{-}, \mathrm{HPO}_{4}^{2-}$, and $\mathrm{PO}_{4}^{3-}$, assuming equilibrium. The processes influencing $\mathrm{P}$ dynamics include 1) release of $\mathrm{P}$ through organic matter degradation, 2) fast reversible sorption on the surface of Fe oxide or calcite 3) slow reversible sorption or diffusion into solid phases, and 4) precipitation/dissolution of the phosphate minerals. Although a large number of phosphate minerals have been identified in solids and sediments (Nriagu and Dell, 1974; Nriagu and Moore, 1984), we only include the most common ones, hydroxyapatite, vivianite and strengite (Table 1), for which solubility constants are available.

Phosphorus removal through sorption is constrained by the amount of sorbing phase $\left(\mathrm{Fe}(\mathrm{OH})_{3}\right.$ or $\mathrm{CaCO}_{3}$ ) and maximum solid phase $\mathrm{P}: \mathrm{Fe}$ and $\mathrm{P}: \mathrm{Ca}$ ratios. In the Fe oxide-rich aquifer, a maximum P:Fe molar ratio of 0.5 (Gunnars et al., 2002) is assumed, while for the calcareous aquifer the maximum P:Ca molar ratio is set to 0.6 (Table 1), the ratio for hydroxyapatite (Freeman and Rowell, 1981). Fast equilibrium sorption of $\mathrm{P}$ is described by a Langmuir isotherm:

$$
\left[\mathrm{P}_{\mathrm{s}-\text { fast }}\right]=\frac{K_{L} X_{T}\left[\sum \mathrm{PO}_{4}(\mathrm{aq})\right]}{1+K_{L}\left[\sum \mathrm{PO}_{4}(\mathrm{aq})\right]}
$$




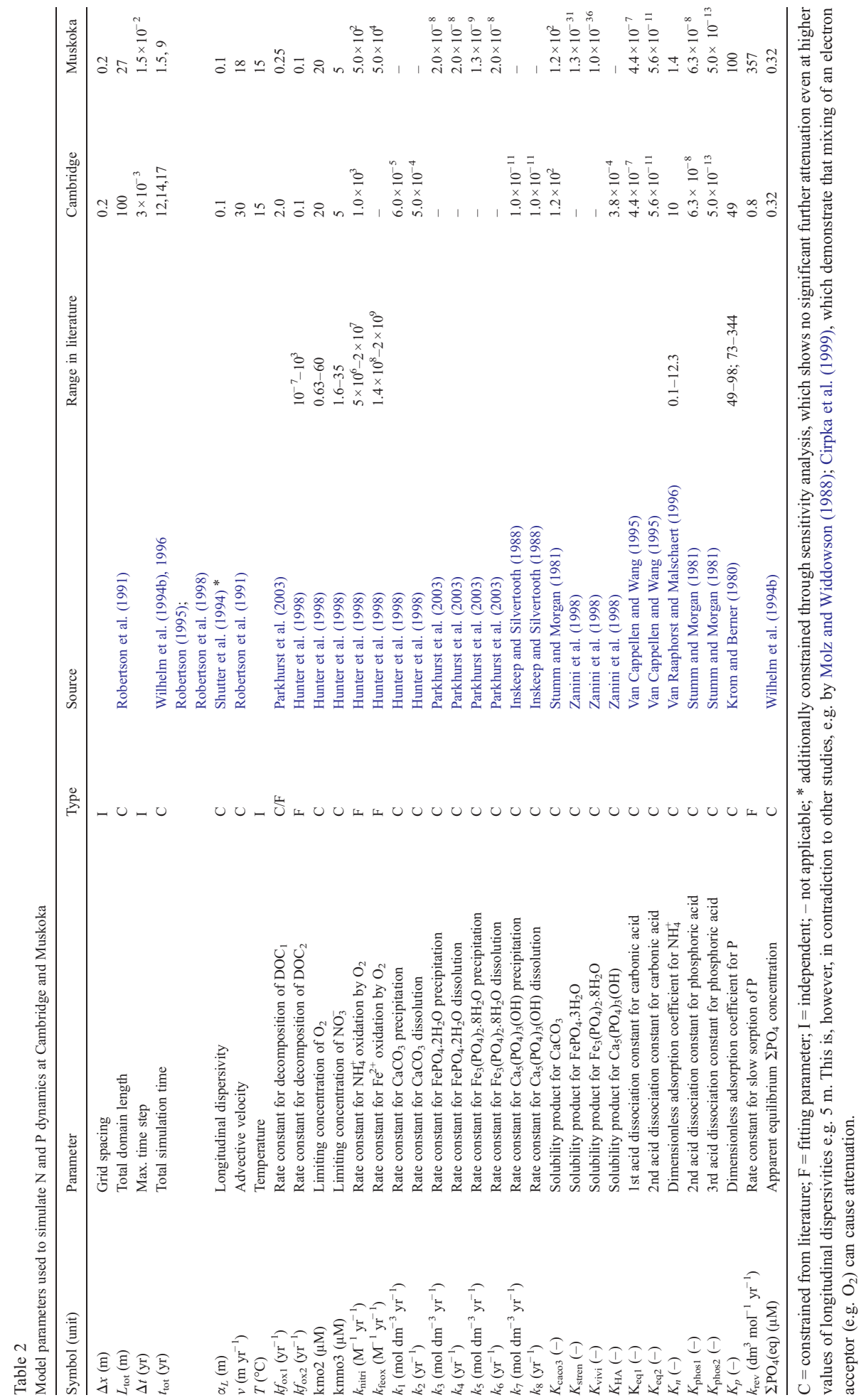


where $\mathrm{P}_{\text {s-fast }}$ is the concentration of $\mathrm{P}$ sorbed through equilibrium sorption $\left(\mathrm{mol} \mathrm{dm}^{-3}\right)$ and $X_{T}$ is the maximum capacity of the aquifer solids $\left(\mathrm{Fe}(\mathrm{OH})_{3}\right.$ or $\left.\mathrm{CaCO}_{3}\right)$ for fast sorption $\left(\mathrm{mol} \mathrm{dm}^{-3}\right)$.In the Fe oxide-rich aquifer, $10 \%$ of the $\mathrm{Fe}(\mathrm{OH})_{3}$ is assumed to be available for fast sorption (Slomp et al., 1996), so that $X_{T}=0.1 * \mathrm{Fe}(\mathrm{OH})_{3}$ (Table 1). Similarly, $5 \%$ of the $\mathrm{CaCO}_{3}$ is available for fast sorption (Cole et al., 1953). Dimensionless adsorption coefficients, $K_{p}$, for Fe oxide and $\mathrm{CaCO}_{3^{-}}$ containing sediments (Krom and Berner, 1980), corrected for ambient porosity (Table 2), were used to constrain the value of the sorption constant $K_{L}\left(\mathrm{M}^{-1}\right)$ (Eq. (3)). The calculation of $K_{L}$ is based on the near-linear behaviour of the Langmuir isotherm at low dissolved P concentrations. The product of the sorption constant $K_{L}\left(\mathrm{M}^{-1}\right)$ and $X_{T}$, divided by $\phi$, is then equivalent to the dimensionless in situ adsorption coefficient $K_{p}$. Since $X_{T}, \phi$, and $K_{p}$ are known, $K_{L}$ can be calculated.

The kinetic removal of $\mathrm{P}$ through slow sorption is described by an empirical relation involving the product of a rate constant $k_{\mathrm{rev}}\left(\mathrm{dm}^{3} \mathrm{~mol}^{-1} \mathrm{yr}^{-1}\right)$, the difference between the maximum capacity of the aquifer solids for slow sorption $\left(S_{T}\right.$ in $\left.\mathrm{mol} \mathrm{dm}{ }^{-3}\right)$ and the amount of sorbed $\mathrm{P}\left(\mathrm{P}_{\text {s-slow }}\right.$ in $\left.\mathrm{mol} \mathrm{dm}{ }^{-3}\right)$, and the departure of the dissolved phosphate concentration, $\Sigma \mathrm{PO}_{4}(\mathrm{aq})$, from an 'apparent' equilibrium value, $\Sigma \mathrm{PO}_{4}$ (eq) (Slomp et al., 1998; Table 1).

$$
R_{\mathrm{SS}}=-k_{\mathrm{rev}}\left(\left[S_{T}\right]-\left[P_{\mathrm{s}-\mathrm{slow}}\right]\right)\left(\left[\Sigma P O_{4}(\mathrm{aq})\right]-\left[\Sigma P O_{4}(\mathrm{eq})\right]\right) .
$$

This slow sorption process is distinct from the precipitation of $\mathrm{P}$ minerals, as it exhibits a maximum sorption capacity $\left(S_{T}\right)$, which is characteristic of the aquifer solid matrix. $S_{T}$ is equal to $0.4 * \mathrm{Fe}(\mathrm{OH})_{3}$ in the $\mathrm{Fe}$ oxide-rich aquifer and to $0.55 * \mathrm{CaCO}_{3}$ in the calcareous aquifer (Table 1). Hence, the sum of $X_{T}$ and $S_{T}$ makes up the total fraction of $\mathrm{Fe}(\mathrm{OH})_{3}$ or $\mathrm{CaCO}_{3}$ available for fast and slow sorption, as determined by the $\mathrm{P}: \mathrm{Fe}$ and $\mathrm{P}: \mathrm{Ca}$ molar ratios. Both sorption processes are assumed to be fully reversible.

The list of parameters used in the simulations is given in Table 2. Most of the values were constrained from literature studies, following the general procedure adopted in similar modelling exercises (e.g. Van Cappellen and Wang, 1996; Canavan et al., 2006). Those denoted as "fitting parameters" were obtained by trial and error by fitting the model to the field data. These include the organic matter degradation rate constants $\left(k f_{\text {ox } 1}\right.$ and $\left.k f_{\text {ox } 2}\right)$, rate constants for the secondary reoxidation reactions $\left(k_{\text {nit }}\right.$ and $\left.k_{\text {feox }}\right)$ and the rate constant for slow kinetic P sorption $\left(k_{\text {rev }}\right)$. A sensitivity analysis is carried out for the most important model parameters.

\section{Model application}

\subsection{Study sites}

Robertson and coworkers have described the geochemistry and hydrogeology of septic system plumes in central Canada in great detail (e.g. Robertson et al., 1991; Wilhelm et al., 1994a,b, 1996; Robertson et al., 1998; Zanini et al., 1998; Robertson, 2003). Here, we test our model by using field data from two well-studied domestic effluent plumes (Cambridge and Muskoka; Fig. 1) that developed in relatively homogeneous, unconfined sandy aquifers. Wastewater collected in the septic tanks flows predominantly vertically through the aerobic unsaturated sediments of the drain field, where it undergoes significant geochemical changes before reaching the water table. The extent of transformation is determined by the initial composition of the wastewater, the subsurface composition and the physical arrangement of the septic system, such as the distance between the tile bed and the water table (Wilhelm et al., 1994a). This distance is 


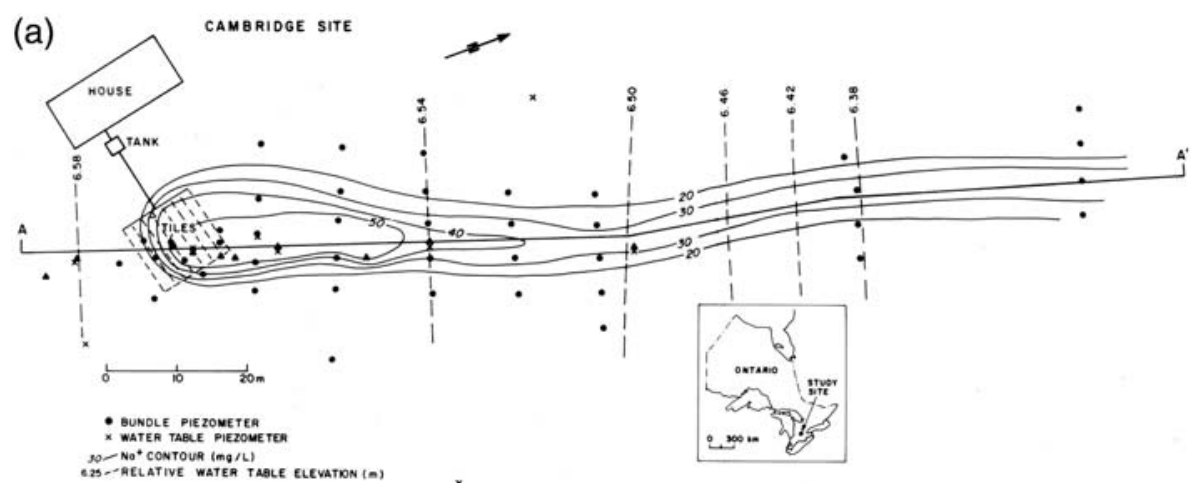

(b)
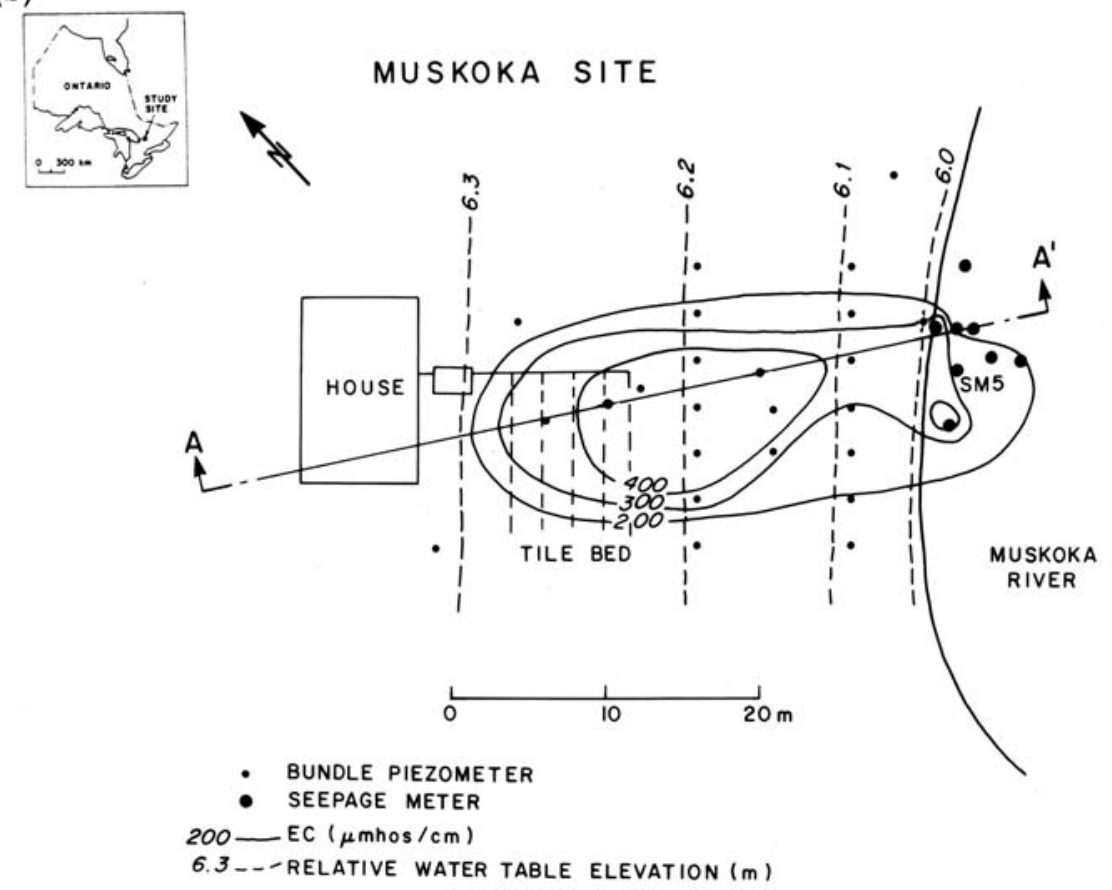

Fig. 1. Vertically averaged groundwater $\mathrm{Na}^{+}$concentration $\left(\mathrm{mg} \mathrm{L}^{-1}\right.$, contour) and electrical conductance $\left(\mu \mathrm{mhos} \mathrm{cm}^{-1}\right.$, contour) at the calcareous (Cambridge) and non-calcareous (Muskoka) sites, respectively. Dashed lines indicate the relative water elevation (m). Closed circles indicate piezometers $(\bullet)$ or seepage meters $(\bullet)$ (Source: Robertson et al., 1991$)$.

about 2-3 $\mathrm{m}$ at the Cambridge and Muskoka sites. Both flow fields in the saturated zone are largely horizontal and characterized by sharp upper and lower plume boundaries which indicate low lateral and vertical dispersion (Robertson et al., 1991). Thus, a 1D approximation is adopted to represent the major processes occurring along the narrow plume core, assuming the effluent source to be below the water table. The septic system at the Cambridge site has been operating continuously since 1977 , serving a family of four, and is situated on a calcareous $(20 \% \mathrm{w} /$ ${ }_{w} \mathrm{CaCO}_{3}$ ) sandy aquifer. The system at the Muskoka site has been operating since 1987 and serves a two-person household. The edge of the tile bed is located $20 \mathrm{~m}$ away from Muskoka 
Table 3

Major characteristics of the septic systems and groundwater at Cambridge and Muskoka

\begin{tabular}{|c|c|c|c|}
\hline Characteristics & Cambridge & Muskoka & Source \\
\hline Redox conditions & Oxic $^{a}$ & $\mathrm{Oxic}^{\mathrm{a}}$ & Wilhelm et al. (1996) \\
\hline $\begin{array}{l}\text { Groundwater flow } \\
\text { velocity }\end{array}$ & $20-40 \mathrm{~m} \mathrm{yr}^{-1}$ & $10-20 \mathrm{~m} \mathrm{yr}^{-1}$ & Robertson et al. (1991) \\
\hline Start of operation & 1977 & 1987 & Robertson et al. (1991) \\
\hline Plume dimensions & $\begin{array}{l}>130 \mathrm{~m} \text { long by } 10 \mathrm{~m} \\
\text { wide in } 1987\end{array}$ & $>20 \mathrm{~m}$ long in 1988 & Robertson et al. (1991) \\
\hline $\mathrm{pH}$ range of plume & $7.1-7.4$ & $4.9-5.9$ & Wilhelm et al. (1996) \\
\hline Porosity & 0.35 & 0.35 & Robertson et al. (1991) \\
\hline Aquifer sorptive phase & $20 \% \mathrm{w} / \mathrm{w} \mathrm{CaCO}_{3}{ }^{\mathrm{b}}$ & $0.54 \%$ w/w Fe-oxide ${ }^{c}$ & Wilhelm et al. (1996)/Zanini et al. (1998) \\
\hline
\end{tabular}

${ }^{a}$ Determined by the presence of detectable $\mathrm{O}_{2}$ concentration of $>3 \mu \mathrm{M}$ (Robertson et al., 1998).

${ }^{\mathrm{b}}$ Equivalent to $2250 \mathrm{mmol} \mathrm{dm}^{-3}$; ${ }^{\mathrm{c}}$ Equivalent to $56 \mathrm{mmol} \mathrm{dm}^{-3}$, assuming a $\rho_{\text {bulk }}=1.7 \mathrm{~kg} \mathrm{dm}^{-3}$.

River and the plume infiltrates a non-calcareous sandy aquifer $(\sim 0.5 \% \mathrm{w} / \mathrm{w}$ Fe oxide content $)$. The main characteristics of the plumes at Cambridge and Muskoka are summarized in Table 3.

Measurements of DOC, $\mathrm{O}_{2}$ and $\mathrm{\Sigma}_{2} \mathrm{PO}_{4}(\mathrm{aq})$ in the saturated zone along the central flow lines of the Cambridge and Muskoka plumes, as given by Wilhelm et al. (1996), are presented in Figs. 2 and 3. The data are actual point measurements along the $x-z$ plane of both plumes (and not depth-
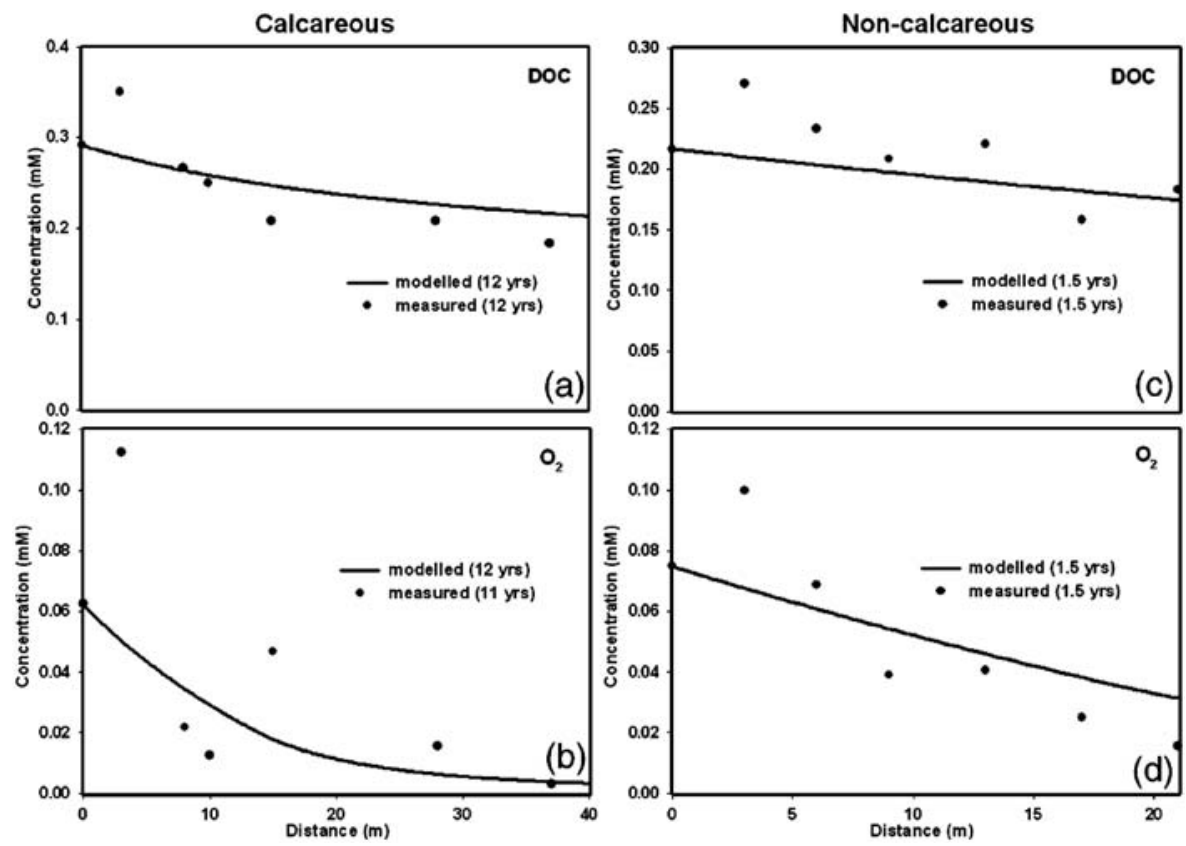

Fig. 2. Measured and modelled results for (a) DOC and (b) $\mathrm{O}_{2}$ along the plume centre line at the calcareous site, and (c) DOC and (d) $\mathrm{O}_{2}$ at the non-calcareous site. Boundary concentrations for DOC and $\mathrm{O}_{2}$ at the calcareous site are 0.29 and $0.063 \mathrm{mM}$, equivalent to 3.5 and $2.0 \mathrm{mg} \mathrm{L}^{-1}$, respectively (Wilhelm et al., 1996). At the non-calcareous site, boundary concentrations for DOC and $\mathrm{O}_{2}$ are set to 0.22 and $0.075 \mathrm{mM}$, equal to 2.6 and $2.4 \mathrm{mg} \mathrm{L}^{-1}$, respectively (Wilhelm et al., 1996). Modelled DOC refers to the sum of the two fractions, $\mathrm{DOC}_{1}$ and $\mathrm{DOC}_{2}$. The source of measured data is Wilhelm et al. (1996). 

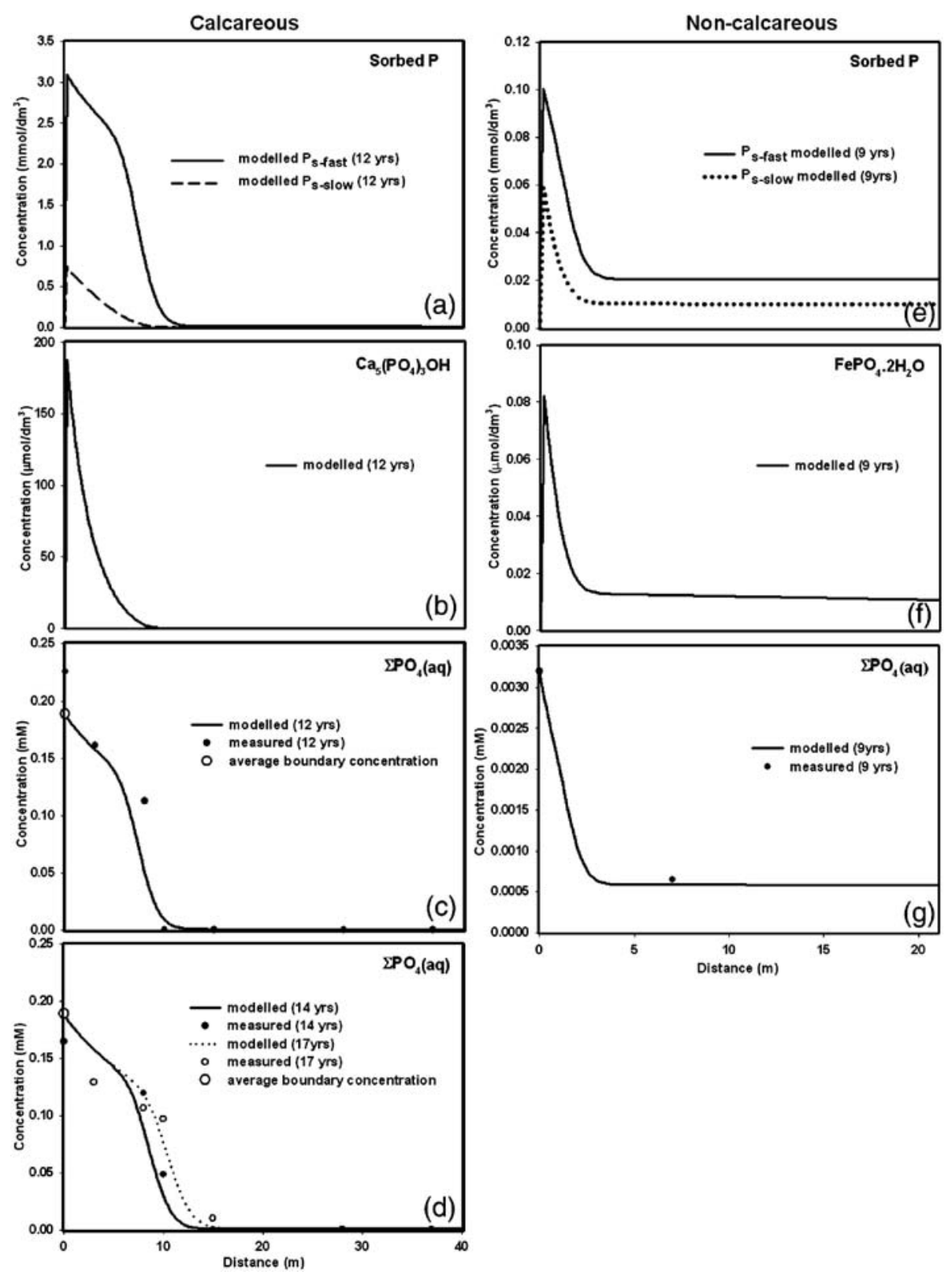

Fig. 3. Measured and modelled concentrations for (a) sorbed $\mathrm{P}$, (b) hydroxyapatite $\left(\mathrm{Ca}_{5}\left(\mathrm{PO}_{4}\right)_{3} \mathrm{OH}\right),(\mathrm{c})$ and (d) $\Sigma \mathrm{PO} 4(\mathrm{aq})$ along the plume centre line at the calcareous site. Measured data in (c) and (d) are from Wilhelm et al. (1996) and Robertson (1995), respectively. The $\Sigma \mathrm{PO}_{4}(\mathrm{aq})$ boundary concentration is $0.19 \mathrm{mM}\left(5.85 \mathrm{mg} \mathrm{L}{ }^{-1}\right)$, equal to the average measured concentration below the tile bed after 10, 14, 17 (Robertson, 1995) and 12 years (Wilhelm et al., 1994b) of loading. Measured and modelled concentrations along the plume centre line at the non-calcareous site for (e) sorbed $\mathrm{P}$, (f) strengite $\left(\mathrm{FePO}_{4} \cdot 2 \mathrm{H}_{2} \mathrm{O}\right)$ and $(\mathrm{g}) \Sigma \mathrm{PO}_{4}(\mathrm{aq})$. Note that the units of the $y$-axis in (f) are in $\mu \mathrm{mol} / \mathrm{dm}^{3}$. Measured data in (g) are from Robertson et al. (1998). The boundary concentration of $\Sigma \mathrm{PO}_{4}(\mathrm{aq})$ is set to $0.0032 \mathrm{mM}\left(0.1 \mathrm{mg} \mathrm{L} \mathrm{L}^{-1}\right)$. The concentration at $x=0 \mathrm{~m}$ refers to the first sampling point below the water table $(\sim 1 \mathrm{~m}$ and $\sim 0.5 \mathrm{~m}$ at the Cambridge and Muskoka sites, respectively; Wilhelm et al., 1994b, 1996) underneath the middle of the tile bed. 
averaged concentrations). The corresponding durations of septic sewage loading at Cambridge are 11 years $\left(\mathrm{O}_{2}\right), 12$ years (all data except $\left.\mathrm{O}_{2}\right)$, and 14 and 17 years $\left(\Sigma \mathrm{PO}_{4}(\mathrm{aq})\right)$ ). At Muskoka, the duration of loading is either 1.5 years $\left(\mathrm{DOC}\right.$ and $\left.\mathrm{O}_{2}\right)$ or 9 years $\left(\Sigma \mathrm{PO}_{4}(\mathrm{aq})\right)$. Up to $90 \%$ of the DOC present in the effluent is removed through oxic degradation in the unsaturated soil zone (Wilhelm et al., 1994b). Nevertheless, significant amounts of wastewater DOC reach the water table at both sites. The simultaneous decrease of DOC and $\mathrm{O}_{2}$ with distance from the tile bed is indicative of aerobic DOC degradation in both plumes. At the Cambridge site, the depressed $\mathrm{O}_{2}$ levels within the plume core $(0.03-0.063 \mathrm{mM})$ contrast with those in the surrounding groundwater, which typically vary from 0.125 to $0.25 \mathrm{mM}$ (Wilhelm et al., 1994b).

Phosphate is strongly attenuated at both sites, especially at Muskoka. Substantial P removal through mineral precipitation occurs as the effluent passes through the unsaturated zone. This amounts to as high as $\sim 23 \%$ at Cambridge and $99 \%$ at the Muskoka site (Robertson et al., 1998). In fact, at the latter site, no $\mathrm{P}$ is detected in the groundwater after 1.5 years of infiltration, while after 9 years of operation, the $\mathrm{P}$ concentration at $7 \mathrm{~m}$ downgradient of the tile field is no more than $0.00065 \mathrm{mM}$. At Cambridge, the groundwater P concentration below the tile bed varies from 0.16 to $0.23 \mathrm{mM}$ (Wilhelm et al., 1994b; Robertson, 1995), implying a fluctuating effluent source. Phosphorus declines rapidly to background concentrations within the first $10 \mathrm{~m}$ along the flow

Table 4

Boundary concentrations (BC) and initial concentrations (IC) for the chemical species used in the simulations for the Cambridge and Muskoka sites

\begin{tabular}{|c|c|c|c|c|}
\hline \multirow[t]{2}{*}{ Species } & \multicolumn{2}{|l|}{ Cambridge } & \multicolumn{2}{|l|}{ Muskoka } \\
\hline & $\mathrm{BC}$ & $\mathrm{IC}$ & $\mathrm{BC}$ & $\mathrm{IC}$ \\
\hline $\mathrm{Ca}^{2+}$ & 2.3 & 2.2 & 1.2 & 0.25 \\
\hline $\mathrm{CaCO}_{3}(\mathrm{~s})$ & & 2250 & & 0.0 \\
\hline $\mathrm{Ca}\left(\mathrm{PO}_{4}\right)_{3} \mathrm{OH}(\mathrm{s})$ (hydroxyapatite) & & 0.0 & & 0.0 \\
\hline $\mathrm{CO}_{2} *$ & 1.0 & 0.38 & 13.33 & 0.77 \\
\hline $\mathrm{CO}_{3}^{2-*}$ & 0.004 & $3.7 \times 10^{-3}$ & $2.0 \times 10^{-6}$ & $1.2 \times 10^{-5}$ \\
\hline $\mathrm{DOC}_{1} * *$ & 0.052 & 0.0 & 0.13 & 0.0 \\
\hline $\mathrm{DOC}_{2} * *$ & 0.24 & 0.24 & 0.09 & 0.09 \\
\hline $\mathrm{Fe}^{2+}$ & 0.003 & 0.004 & $7.5 \times 10^{-4}$ & $3.4 \times 10^{-4}$ \\
\hline $\mathrm{Fe}_{3}\left(\mathrm{PO}_{4}\right)_{2 .} 8 \mathrm{H}_{2} \mathrm{O}(\mathrm{s})$ (vivianite) & & 0.0 & & 0.0 \\
\hline $\mathrm{FePO}_{4} \cdot 2 \mathrm{H}_{2} \mathrm{O}(\mathrm{s})$ (strengite) & & 0.0 & & 0.0 \\
\hline $\mathrm{Fe}(\mathrm{OH})_{3}(\mathrm{~s})$ & & 0.0 & & 56.0 \\
\hline $\mathrm{H}_{2} \mathrm{PO}_{4}^{-* * *}$ & 0.105 & $1.3 \times 10^{-4}$ & $3.18 \times 10^{-3}$ & $2.8 \times 10^{-4}$ \\
\hline $\mathrm{HCO}_{3}^{-*}$ & 5.6 & 3.3 & 0.46 & 0.27 \\
\hline $\mathrm{H}^{+}(\mathrm{pH})$ & $7.9 \times 10^{-5}(7.1)$ & $5.0 \times 10^{-5}(7.3)$ & $0.013(4.9)$ & $1.3 \times 10^{-3}(5.9)$ \\
\hline $\mathrm{HPO}_{4}^{2-* * *}$ & 0.084 & $1.7 \times 10^{-4}$ & $1.6 \times 10^{-5}$ & $1.4 \times 10^{-5}$ \\
\hline $\mathrm{Na}^{+}$ & 4.0 & 0.17 & 2.0 & 0.1 \\
\hline $\mathrm{NH}_{4}^{+}$ & 0.006 & $3.5 \times 10^{-3}$ & 0.035 & 0.013 \\
\hline $\mathrm{NH}_{4(\mathrm{ads})}(\mathrm{s})$ & & 0.012 & & 0.018 \\
\hline $\mathrm{NO}_{3}^{-}$ & 1.9 & 2.0 & 3.0 & 0.28 \\
\hline $\mathrm{O}_{2}$ & 0.063 & 0.19 & 0.075 & 0.19 \\
\hline $\mathrm{PO}_{4}^{3-* * *}$ & $5.0 \times 10^{-7}$ & $1.7 \times 10^{-9}$ & $6.0 \times 10^{-13}$ & $6.0 \times 10^{-12}$ \\
\hline $\mathrm{P}_{\mathrm{s}-\mathrm{fast}}(\mathrm{s})$ & & $3.4 \times 10^{-3}$ & & 0.03 \\
\hline $\mathrm{P}_{\mathrm{s} \text {-slow }}(\mathrm{s})$ & & 0.0 & & 0.0 \\
\hline * DIC & 6.6 & 3.7 & 13.8 & 1.0 \\
\hline $\begin{array}{l}* * \text { Units in moles of carbon per unit volume pore water } \\
* * * \sum \mathrm{PO}_{4}(\mathrm{aq})\end{array}$ & 0.189 & $3.0 \times 10^{-4}$ & $3.2 \times 10^{-3}$ & $3.0 \times 10^{-4}$ \\
\hline
\end{tabular}

The solid species are marked with (s). Units: solute (mM), solids (mmol dm$\left.{ }^{-3}\right)$. 
path after 12 years of effluent infiltration (Wilhelm et al., 1994b). Subsequent monitoring of the P concentrations reveals a steady downgradient plume progression, extending to $15 \mathrm{~m}$ after 17 years. Despite the low P concentrations at the Muskoka site, modelling the fate of $\mathrm{P}$ in the saturated zone still remains of interest, considering that $\mathrm{P}$ concentrations as low as $0.00097 \mathrm{mM}$ $(\sim 0.03 \mathrm{mg} / \mathrm{L}$ ) have been observed to stimulate algal growth in aquatic environments (Dillon and Rigler, 1974; Schindler 1977) and thus, off-site migration allows a potential impact to adjacent surface water bodies.

At Cambridge, the $\mathrm{pH}$ of the plume (not shown) remains near neutral due to the acid buffering capacity of the calcareous aquifer sediments. At Muskoka, however, the effect of acidity production from aerobic degradation and secondary reoxidation reactions causes the $\mathrm{pH}$ to drop down to $\sim 4.9$ at the water table (Wilhelm et al., 1996).

\subsection{Boundary and initial conditions}

In the model, we assume a horizontal flow path along the centre of the plume. The solute concentrations at the inlet $(x=0 \mathrm{~m})$ are set equal to the concentration at the first sampling point below the water table underneath the middle of the tile bed (Wilhelm et al., 1994b, 1996), assuming a Dirichlet boundary condition (fixed concentration) for all dissolved species. At the downstream outflow $(x=L \mathrm{~m})$, a Neumann boundary condition (zero concentration gradient) is imposed. In both cases, the domain length is such that the plumes of the compounds of interest do not reach the outflow boundary. The initial concentrations are equal to the pristine background concentration of each species (Wilhelm et al., 1996). All boundary and initial concentrations are summarized in Table 4.

\section{Results and discussion}

\subsection{DOC, $\mathrm{O}_{2}$ and $P$ dynamics in oxic sewage plumes}

Modelled concentrations of DOC, $\mathrm{O}_{2}$ and $\Sigma \mathrm{PO}_{4}(\mathrm{aq})$ are generally within the range of measured values and show the same trends with distance (Figs. 2 and 3). This implies that the model reasonably represents the most important processes occurring in the aquifers.

Model results confirm that the decline in $\mathrm{O}_{2}$ is primarily related to aerobic degradation of DOC, and at the Muskoka site, additionally to the oxidation of effluent $\mathrm{Fe}^{2+}$. The effect of nitrification on $\mathrm{O}_{2}$ removal and $\mathrm{NO}_{3}^{-}$production is negligible. Hence, nitrate behaves conservatively in both systems and, therefore, is not discussed further. The rate constants for degradation necessary to fit the measured concentration profiles suggest that the labile DOC fraction at the Cambridge site is one order of magnitude more reactive than at the Muskoka site $\left(k f_{\mathrm{ox} 1}=2.0 \mathrm{yr}^{-1}\right.$ and $0.25 \mathrm{yr}^{-1}$, respectively). Since the source of DOC is similar, this difference in DOC reactivity could reflect more extensive degradation in the unsaturated zone at Muskoka. The depth of the unsaturated zone at Cambridge $(2 \mathrm{~m})$ is somewhat shallower than that at Muskoka (3 m) (Robertson et al., 1991). The reactivity of the less labile fraction, $\mathrm{DOC}_{2}$, is similar at both sites $\left(k f_{\mathrm{ox} 2}=0.1 \mathrm{yr}^{-1}\right)$. The values of $k_{\text {nitri }}$ and $k_{\text {feox }}$ used to fit the $\mathrm{O}_{2}$ data fall outside the ranges observed in literature. This, however, has no significant effect on $\mathrm{P}$ dynamics. Modelled $\mathrm{pH}$ values at Muskoka and Cambridge are constant throughout the plume at $\sim 4.9$ and 7.1 respectively (not shown).

The model results for $\Sigma \mathrm{PO}_{4}(\mathrm{aq})$ show that sorption processes (both fast and slow) are the main mechanisms that limit $\mathrm{P}$ plume migration in groundwater. At the Cambridge site, the model also 
predicts some hydroxyapatite precipitation near the source inlet (Fig. 3b), which, however, accounts only for a minor fraction of the total $\mathrm{P}$ retention. This indicates that hydroxyapatite precipitation is relatively ineffective at controlling $\mathrm{P}$ concentrations in oxidizing and calcareous aquifers, as also suggested by Robertson et al. (1998). Fast sorption accounts for $86 \%$ of the total mass loss and is thus the predominant sorption process. Similar results, with $80 \%$ of adsorption occurring within seconds, were reported for laboratory experiments with calcite (Kuo and Lotse, 1972; House and Donaldson, 1986). The calculated $\left(\mathrm{P}_{\mathrm{s} \text {-fast }}+\mathrm{P}_{\text {s-slow }}\right): \mathrm{CaCO}_{3}$ ratios at any point along the plume where $\mathrm{P}$ retention is taking place vary between $1 \times 10^{-4}$ and $2 \times 10^{-3}$, and thus also fall within the range observed in experiments (House and Donaldson, 1986; Millero et al., 2001).

At the Muskoka site, fast sorption is again the main mechanism for P retention (Fig. 3e). Slow sorption is also important, however, and accounts for 33\% of total P sorption, which could be due to the high specific surface area of the Fe oxides (Parfitt, 1989). In addition, the model predicts some strengite precipitation, as suggested previously by Robertson et al. (1998). This process is, however, quantitatively unimportant (Fig. 3f). Precipitation of vivianite is negligible under oxidizing conditions. Robertson (2003) proposes that variscite precipitation is another important $\mathrm{P}$ removal mechanism at this site, particularly in the unsaturated zone. Due to lack of sufficient data to constrain the $\mathrm{Al}^{3+}$ concentrations, variscite was not included as a possible solid in the saturated groundwater system.

A sensitivity analysis is performed to assess the effects of key model parameters controlling P removal on dissolved $\mathrm{P}$ concentrations in the plume (Fig. 4). Our results indicate that sorption is the major attenuation mechanism in both calcareous and non-calcareous groundwater systems. Phosphorus attenuation through precipitation is marginal, as shown by the model runs that consider removal through precipitation only (Fig. 4a and d) and by the model's insensitivity to variations in the kinetic constants that determine $\mathrm{P}$ mineral precipitation (Fig. $4 \mathrm{c}$ and $\mathrm{f}$ ). When only precipitation is taken into account in the Muskoka case, an increase in $\Sigma \mathrm{PO}_{4}(\mathrm{aq})$ along the flow line is observed as a result of organic matter degradation (Fig. 4d).

Comparison of the modelled $\mathrm{P}$ plumes from runs considering fast sorption or slow sorption only (Fig. 4a) demonstrates that the extent of $\mathrm{P}$ removal in the calcareous site is primarily determined by fast equilibrium sorption, which is highly sensitive to the value of $K_{p}$ (Fig. $4 \mathrm{~b}$ ). In fact, fast sorption alone can reproduce the drop in $\mathrm{P}$ at around $10 \mathrm{~m}$ observed in the field. In the Fe oxide-rich case, variations in the value of $K_{p}$ cause slight divergences from the background downgradient $\Sigma \mathrm{PO}_{4}(\mathrm{aq})$ concentration (Fig. 4e). If slow sorption is considered on its own (Fig. 4d), the actual $\mathrm{P}$ retention increases due to an enhanced rate of $\mathrm{P}_{\text {s-slow }}$ formation. This removal is driven by the greater availability of dissolved $\mathrm{P}$ that stabilizes at a lower value than that established by the fast sorption (Fig. 4d).

\subsection{Scenarios: continued loading and decommissioning}

We perform a set of prognostic simulations to assess the progression of the P plume on the short term (by the year 2004) and over longer time periods (next 50 years) in both aquifers. All parameters are assumed to remain unchanged over the time scale of the simulations. At the calcareous site, the P front is expected to have reached $20 \mathrm{~m}$ by the year 2004 and $\sim 50 \mathrm{~m}$ within the next 50 years (Fig. 5a). The plume advancement at the non-calcareous site is relatively unimportant (Fig. 5b), mainly due to the combined effect of a low P loading and high sorption capacity of the aquifer solids for P. If an infiltrating P concentration of $0.19 \mathrm{mM}$ is assumed in both scenarios, the plume in the non-calcareous case travels less than half the 

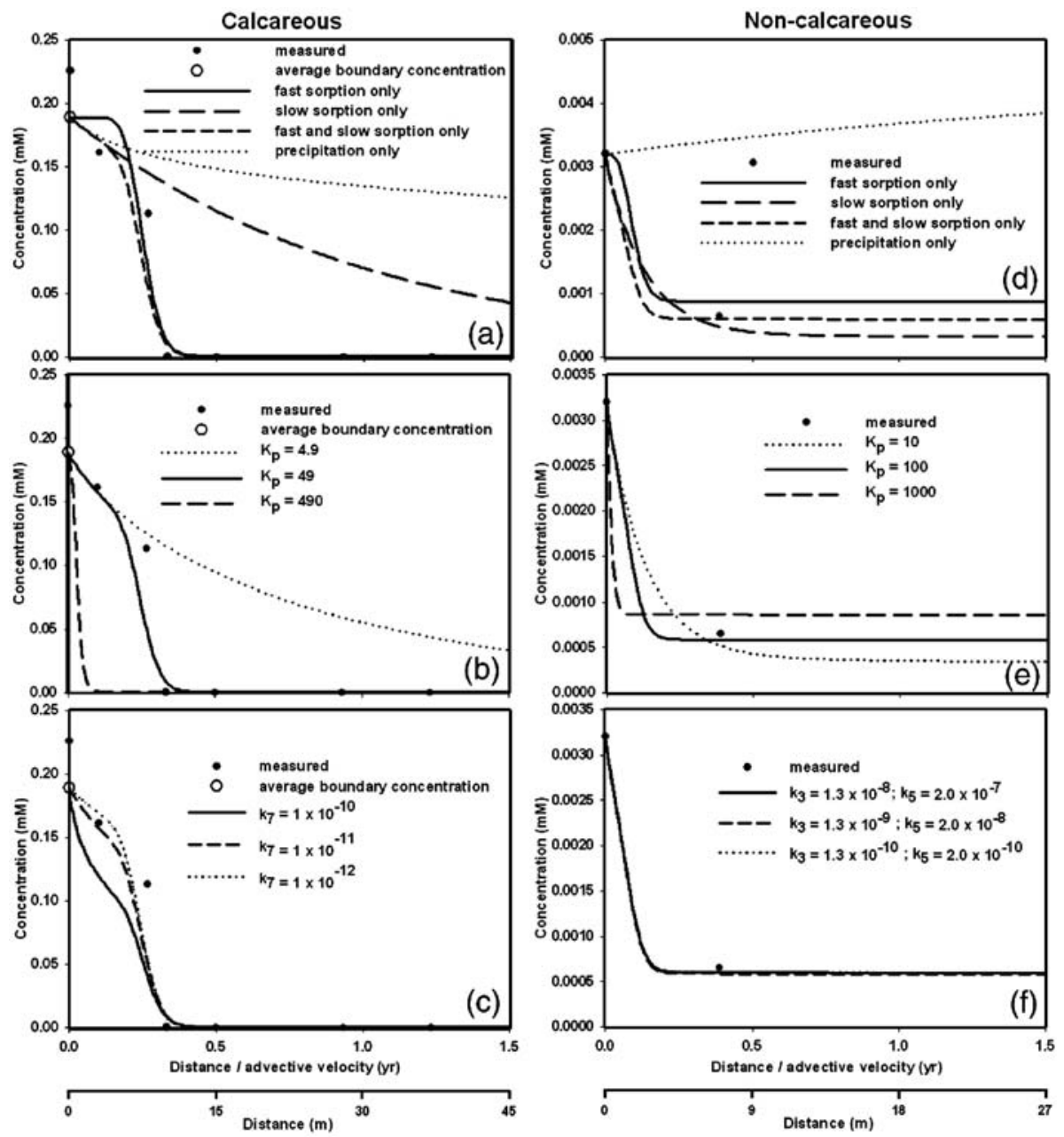

Fig. 4. Sensitivity analyses of processes that remove $\Sigma \mathrm{PO}_{4}(\mathrm{aq})(\mathrm{a}$ and d). Sensitivity analyses of model parameters that control $\Sigma \mathrm{PO}_{4}$ (aq) removal, namely the dimensionless distribution coefficient for fast sorption $\left(K_{p}\right.$; b and e), rate constant for precipitation of hydroxyapatite $\left(k_{7} ; \mathrm{c}\right)$, strengite $\left(k_{3} ; \mathrm{f}\right)$ and vivianite $\left(k_{5} ; \mathrm{f}\right)$. Field measurements for the calcareous and non-calcareous sites are taken from Wilhelm et al. (1996) and Robertson et al. (1998), respectively.

distance by the year 2004 and only one fifth of that in the calcareous scenario in the next 50 years (not shown).

Trends in solid phases that attenuate dissolved $\mathrm{P}$ indicate a steady increase in the total integrated amount of solid $\mathrm{P}$ with time in both cases (Fig. 5b and d). In addition, a progressive shift in the prevalence of the solid forms, from $\mathrm{P}_{\text {s-fast }}$ to $\mathrm{P}_{\mathrm{s} \text {-slow }}$ to $\mathrm{P}$ minerals occurs. At the noncalcareous site, $\mathrm{P}_{\text {s-slow }}$ formation predominates with time, causing a decrease in the total $\Sigma \mathrm{PO}_{4}$ (aq). This is followed by a decrease in $\mathrm{P}_{\mathrm{s} \text {-fast }}$ that stabilizes at a lower background value.

In a study by Robertson and Harman (1999) on two decommissioned calcareous septic sites (Langton and Long Point 2), groundwater P concentrations were observed to persist at virtually unchanged levels one year (Langton) or two years (Long Point 2) after active sewage loading had stopped. These authors proposed a number of potential mechanisms to explain the continued 

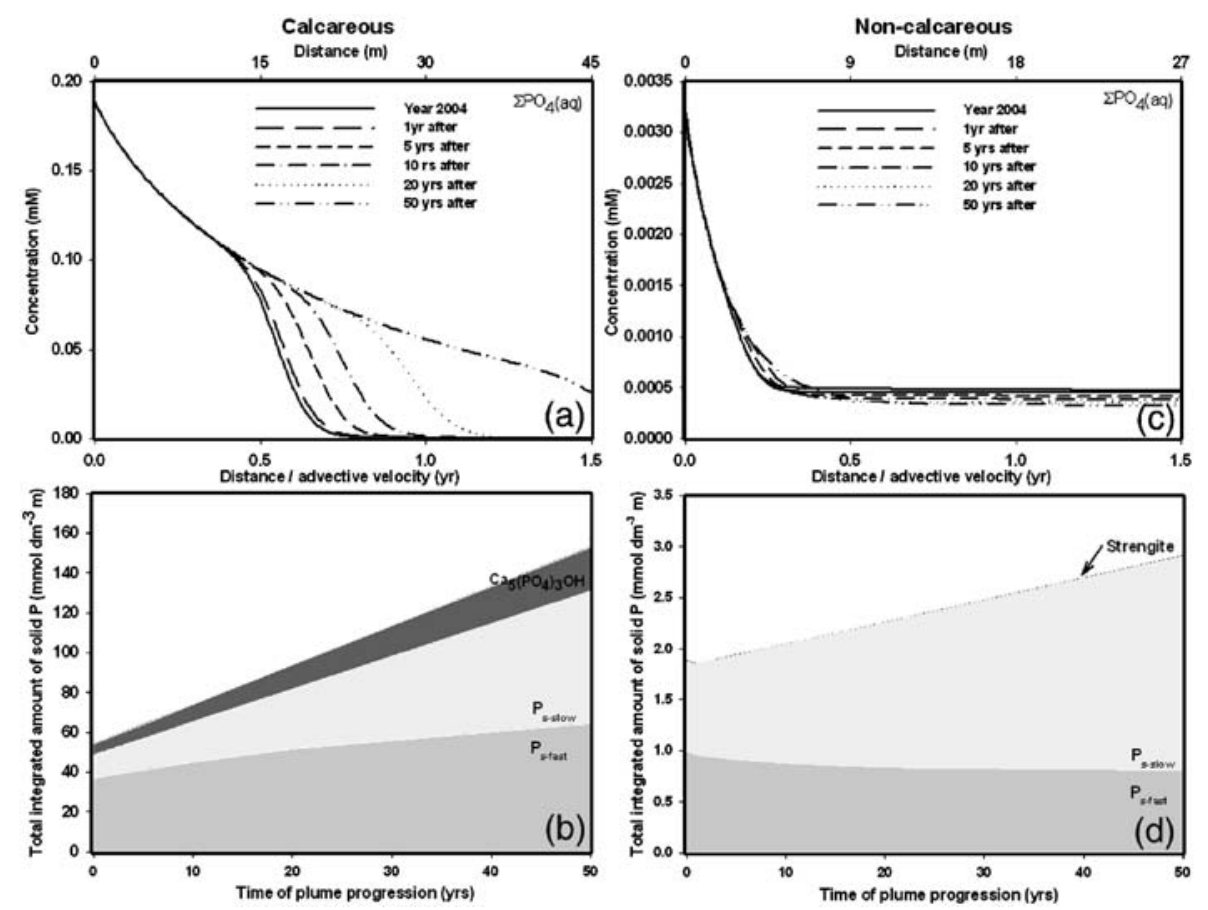

Fig. 5. Simulated $\Sigma \mathrm{PO}_{4}(\mathrm{aq})$ profiles in 2004 and subsequent $\mathrm{P}$ breakthrough curves against normalized distance (distance/ advective velocity) at the (a) calcareous and (c) non-calcareous sites. Plots (b) and (d) show the corresponding amounts of integrated $\mathrm{P}$ solid in the form of $\mathrm{P}_{\mathrm{s} \text {-fast }}, \mathrm{P}_{\mathrm{s} \text {-slow }}$ and $\mathrm{P}$ mineral. Time 0 refers to year 2004.

presence of soluble $\mathrm{P}$, such as desorption, intra-particle diffusion and $\mathrm{P}$ mineral dissolution. Here, we investigate the response of a calcareous and non-calcareous aquifer system to a hypothetical discontinuation of the sewage loading in 2004. In these prognostic simulations, the concentrations at the upstream end of the flowpath are set equal to the pristine groundwater concentrations, while initial concentrations are equal to resultant species distributions after 27 or 17 years (year 2004) of sewage infiltration, respectively. All other parameters remain as in the baseline simulations. The present-day position and subsequent propagation of the $\Sigma \mathrm{PO}_{4}(\mathrm{aq})$ plumes at specific time intervals after decommissioning are shown in Fig. 6.

The results show that the $\mathrm{P}$ plume is much more mobile and persistent in the calcareous environment than in the Fe oxide-rich aquifer. For instance, in the calcareous case, the plume travels a distance of $10 \mathrm{~m}$ within 20 years after decommissioning, as compared to $2 \mathrm{~m}$ at the non-calcareous scenario. This difference between the two sites remains when the distance is normalized with respect to the advective velocity (Fig. 6a and c; Table 2). After 50 years of source decommissioning, the P front at the non-calcareous site disappears completely, whereas further plume advancement is observed at the calcareous site. Interestingly, in the latter scenario, the concentration of $\mathrm{P}$ at $25 \mathrm{~m}$ from the source after 50 years of source decommissioning is comparable to that predicted after 50 years of sewage loading (Fig. 5a). This is in line with the conclusion drawn by Robertson and Harman (1999), that in the case of oxidizing P plumes in decommissioned calcareous systems, downgradient dissolved $\mathrm{P}$ concentrations are likely to persist for years. Although no significant changes in dissolved $\mathrm{P}$ concentrations were observed in the field during the first few years of source 

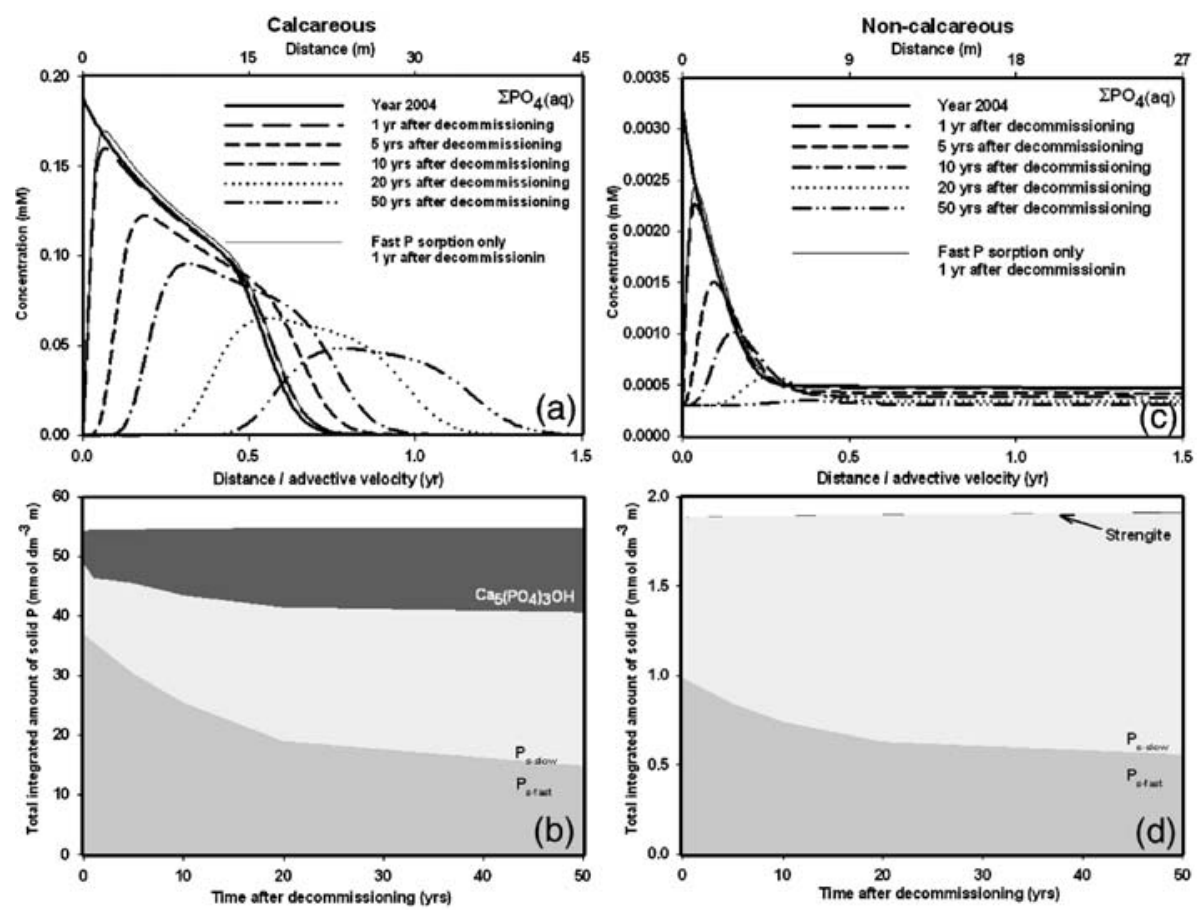

Fig. 6. Simulated $\Sigma \mathrm{PO}_{4}(\mathrm{aq})$ profiles in 2004 and subsequent decreasing P plumes against normalized distance, at different times after decommissioning of the source effluent at (a) the calcareous site and (c) the non-calcareous site. Plots (b) and (d) show the corresponding amounts of integrated $\mathrm{P}$ solid in the form of $\mathrm{P}_{\mathrm{s} \text {-fast }}, \mathrm{P}_{\mathrm{s} \text {-slow }}$ and $\mathrm{P}$ mineral. Time 0 refers to year 2004.

decommissioning, our model results show that considerable attenuation will occur after a few decades.

The total integrated amount of solid-bound $\mathrm{P}$ remains essentially constant after discontinuation of the source (Fig. $6 \mathrm{~b}$ and $\mathrm{d}$ ). However, a gradual interconversion is observed over time at both sites. At the calcareous site, desorbed $\mathrm{P}_{\mathrm{s} \text {-fast }}$ changes progressively to $\mathrm{P}_{\mathrm{s} \text {-slow }}$ and then to the ultimate mineral precipitate, hydroxyapatite (Fig. 6b). The overall amount of total sorbed $\mathrm{P}\left(\mathrm{P}_{\mathrm{s} \text {-fast }}+\mathrm{P}_{\mathrm{s} \text {-slow }}\right)$ decreases from $48.7 \mathrm{mmol} \mathrm{dm}{ }^{-3} \mathrm{~m}$ on the date of decommissioning to $40.5 \mathrm{mmol} \mathrm{dm} \mathrm{dm}^{-3} \mathrm{~m}$ after 50 years. $\mathrm{P}_{\mathrm{s} \text {-slow }}$ increases at the expense of $\mathrm{P}_{\text {s-fast }}$ (Fig. 6b). The $\sim 3$-fold increase in total integrated amount of hydroxyapatite (from $1.87 \mathrm{mmol} \mathrm{dm}^{-3} \mathrm{~m}$ on the date of decommissioning to $4.76 \mathrm{mmol} \mathrm{dm}^{-3} \mathrm{~m}$ after 50 years of decommissioning) shows that mineral precipitation becomes relatively more important on the long term. During the whole time period, the groundwater in the plume remains supersaturated with the maximum SI indices for hydroxyapatite ranging from +6.5 after the first year of decommissioning to +5.0 after 50 years. Although the relatively slow rate of $\mathrm{P}$ precipitation (Freeman and Rowell, 1981; Robertson et al., 1998) limits the aquifer's attenuation capacity, it can still be considered as an effective trapping mechanism for $\mathrm{P}$ on the long term.

Phosphorus behavior in the decommissioned Fe oxide-rich scenario is different from the calcareous case. The total amount of precipitated strengite does not vary significantly between the day of decommissioning and 50 years later, and is insignificant compared to the total sorbed P. 
However, as in the calcareous case, both desorption of $\mathrm{P}_{\mathrm{s} \text {-fast }}$ (Fig. 6c) and conversion to $\mathrm{P}_{\mathrm{s} \text {-slow }}$ (Fig. 6d) are observed over time.

\subsection{Role of sorption capacity and DOC loading for N:P ratios}

The $\mathrm{N}$ and $\mathrm{P}$ dynamics in aquifers with high nutrient loading strongly determine the N:P ratio in the groundwater discharge, and thus, the ecological impact on surface waters. In this set of simulations, we use the model setup for the Muskoka site to illustrate the role of the availability of a sorbing phase for $\mathrm{P}$ in aquifers for $\mathrm{N}$ :P ratios in groundwater discharge. We choose the Muskoka site, because it allows us to assess the full range of possible outcomes, from complete retention of $\mathrm{P}$ to the "worse case" scenario where discharge of $\mathrm{P}$ occurs despite the presence of $\mathrm{Fe}(\mathrm{OH})_{3}$. In the latter scenario, only the $\mathrm{N}: \mathrm{P}$ ratio of the upstream wastewater-contaminated recharge, $(\mathrm{N}: \mathrm{P})_{\text {in }}$, is varied. The $(\mathrm{N}: \mathrm{P})_{\text {in }}$ ratios vary from 1000 , corresponding to the value for the Muskoka site, to 6, which is at the lower range of the typical N:P ratios for sewage effluents (Weiskel and Howes, 1992). For the entire $(\mathrm{N}: \mathrm{P})_{\text {in }}$ range, the total septic inflow $\mathrm{N}$ concentration is kept constant $\left(\mathrm{NO}_{3}^{-}=3.0 \mathrm{mM}\right.$ and $\left.\mathrm{NH}_{4}^{+}=0.035 \mathrm{mM}\right)$ while $\Sigma \mathrm{PO}_{4}(\mathrm{aq})$ increases from $0.0032 \mathrm{mM}$ to $0.5 \mathrm{mM}$. The reason why only the $\mathrm{P}$ concentrations are varied, is that the main $\mathrm{N}$ reaction occurring readily in the oxygenated unsaturated zone involves the transformation of $\mathrm{NH}_{4}^{+}$to $\mathrm{NO}_{3}^{-}$through nitrification, which does not influence the resultant $\mathrm{N}: \mathrm{P}$ ratios. We consider aquifers with a wide range of sorption capacities. In each case, $50 \%$ of the $\mathrm{Fe}(\mathrm{OH})_{3}$ is able to sorb $\mathrm{P}$ through fast and slow sorption. Sorption capacities vary from $10^{-5} \% \mathrm{w} / \mathrm{w} \mathrm{Fe}(\mathrm{OH})_{3}$, representing aquifers with virtually no sorption capacity, to $5 \% \mathrm{w} / \mathrm{w} \mathrm{Fe}(\mathrm{OH})_{3}$. The Muskoka site, with an Fe oxide content of $0.54 \% \mathrm{w} / \mathrm{w}$, lies in between both limits.

Sensitivity to changes in aquifer sorption capacity and $(\mathrm{N}: \mathrm{P})_{\mathrm{in}}$, two of the main site characteristics that affect $\mathrm{P}$ transport, is evaluated by recording the pore solution N:P ratio at $20 \mathrm{~m}$ downgradient of the tile bed, $(\mathrm{N}: \mathrm{P})_{\text {out }}$, after a simulation period of 17 years. This is the number of years the Muskoka site has been in operation until 2004. The selected distance is equivalent to the minimum permissible setback between septic systems and freshwater bodies, as in the case of Muskoka River in the Muskoka scenario (Robertson, 1995). The effect of denitrification on the $(\mathrm{N}: \mathrm{P})_{\text {out }}$ is also analyzed in a model run with a high-DOC recharge $(50 \mathrm{mg}$ $\mathrm{L}^{-1}$ or $4.2 \mathrm{mM}$; equivalent to the DOC concentration in the tile effluent entering the unsaturated zone at the Muskoka site; Robertson et al., 1991). This is regarded as the upper limit for the DOC concentration reaching the water table in the absence of DOC degradation in the unsaturated zone.

$(\mathrm{N}: \mathrm{P})_{\text {out }}$ ratios exhibit three distinct regimes as a function of the sorption capacity (Fig. 7): an inclined plane at low sorption capacities, a "plateau" of high $(\mathrm{N}: \mathrm{P})_{\text {out }}$ at high sorption capacities, and a distinct transition zone. At low sorption capacities, a 1:1 relationship between $(\mathrm{N}: \mathrm{P})_{\text {out }}$ and $(\mathrm{N}: \mathrm{P})_{\text {in }}$ is observed, due to the low Fe oxide content which causes $\mathrm{P}$ breakthrough without any significant attenuation. Thus, in aquifers with sorption capacities lower than $0.02 \% \mathrm{w} / \mathrm{w} \mathrm{Fe}(\mathrm{OH})_{3}$, the $\mathrm{P}$ concentration of the discharging groundwater is potentially as high as $0.0032-0.5 \mathrm{mM}$, by far exceeding the $0.6 \mu \mathrm{M}$ threshold concentration that triggers the development of eutrophic conditions in surface water bodies (Ptacek, 1998). Corresponding P fluxes range from 0.054 to $9.0 \mathrm{mM} \mathrm{m}^{-2}$ $\mathrm{yr}^{-1}$, and are comparable to rates of submarine groundwater discharge of $\mathrm{P}$ into Apalachicola bay, Florida (Corbett et al., 2002). Sorption capacities higher than $0.02 \% \mathrm{w} / \mathrm{w} \mathrm{Fe}(\mathrm{OH})_{3}$ are sufficient to attenuate the $\mathrm{P}$ plume down to background concentrations, giving rise to elevated (N:P) out ratios. The plateau at high sorption capacities shows that, depending on the combination of sorption capacity and effluent $(\mathrm{N}: \mathrm{P})_{\text {in }}$, the $(\mathrm{N}: \mathrm{P})_{\text {out }}$ ratio could increase by up to four orders of magnitude 


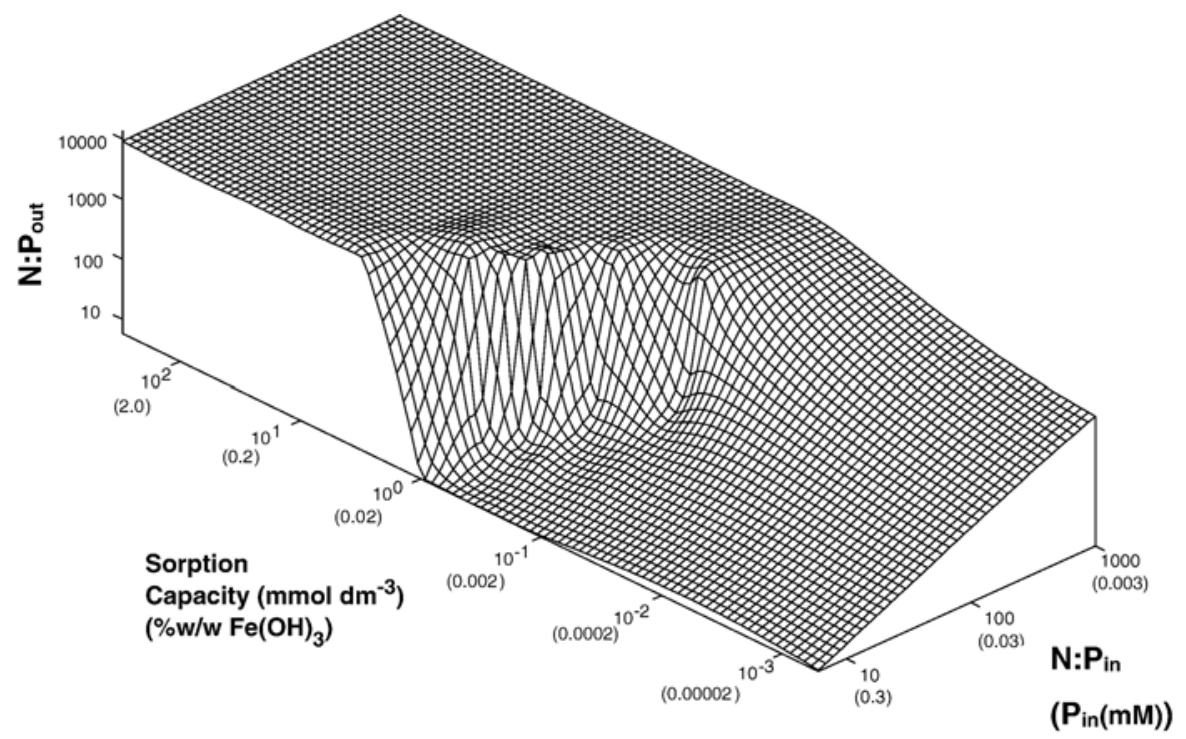

Fig. 7. Variation of $(\mathrm{N}: \mathrm{P})_{\text {out }}$ as a function of sorption capacity $\left(\mathrm{mmol} \mathrm{dm}{ }^{-3}\right)$ or $\% \mathrm{w} / \mathrm{w} \mathrm{Fe}(\mathrm{OH})_{3}$, and effluent $\mathrm{P}_{\text {in }}(\mathrm{mM})$ or $(\mathrm{N}: \mathrm{P})_{\text {in }} 20 \mathrm{~m}$ from the source, after 17 years of simulation time in the non-calcareous site. The 84 data points were interpolated by Kriging.

relative to $(\mathrm{N}: \mathrm{P})_{\text {in }}$. The $(\mathrm{N}: \mathrm{P})_{\text {out }}$ ratio is generally controlled by $\mathrm{P}$ retention through sorption, although $\mathrm{P}$ mineral precipitation becomes relatively more important over longer time scales.

In all model runs, including the one with a high-DOC infiltrate, the extent of denitrification is limited by DOC availability. This is consistent with various other field and modelling studies of denitrification (Wilhelm et al., 1994a,b; MacQuarrie et al., 2001), where the lack of appropriate conditions for denitrification often results in persistently elevated $\mathrm{NO}_{3}^{-}$groundwater concentrations. The high-DOC simulation shows a slight decrease in $(\mathrm{N}: \mathrm{P})_{\text {out }}$ from 6411 to 2512 at Muskoka, as a result of denitrification (not shown). However, the continuous supply of effluent $\mathrm{NO}_{3}^{-}$is sufficient to degrade the available DOC pool and to prevent the onset of $\mathrm{Fe}(\mathrm{OH})_{3}$ reduction, thus allowing the sorption capacity of the aquifer for $\mathrm{P}$ to be maintained.

\section{Conclusions}

The application of a RTM for N and P biogeochemistry in two aquifers impacted by septic effluent (Cambridge and Muskoka) illustrate that nutrient dynamics in the contaminated groundwaters are strongly dependent on the properties of the aquifer material and the effluent composition. The model predictions for DOC, $\mathrm{O}_{2}$ and dissolved $\mathrm{P}$ concentration profiles are generally in good agreement with the field observations. Our approach, which differentiates $\mathrm{P}$ removal into three distinct processes, namely, fast sorption, slow sorption and mineral precipitation, provides a realistic representation of the overall $\mathrm{P}$ dynamics. $\mathrm{NO}_{3}^{-}$behaves essentially as a conservative tracer in the oxic aquifer systems.

Although significant removal occurs before the P plume reaches the water table, model results show pronounced differences in the downstream dissolved $\mathrm{P}$ distributions in calcareous and noncalcareous groundwater systems after plume progression and decommissioning. Attenuation occurs mainly through sorption and to a lesser extent through kinetically-limited precipitation of 
phosphate minerals. The latter process, however, becomes more important over longer timescales. The precipitation of variscite and another five $\mathrm{Fe}-\mathrm{P}$ minerals (lipscombite, rockbridgite, beraunite, tinticite and cocaxonite) identified by Zanini et al. (1998) to potentially occur in the unsaturated zone at the calcareous Cambridge site, as well as numerous other Fe-P minerals (Nriagu and Dell, 1974; Nriagu and Moore, 1984) are excluded from the model reaction network. These minerals, however, may also play an important role at the non-calcareous site (Robertson, 2003). Similarly, $\mathrm{P}$ removal through the precipitation of $\mathrm{Ca}-\mathrm{P}$ minerals other than hydroxyapatite is possible in the calcareous environment (Baker et al., 1998). Additional time-series monitoring at the Cambridge and Muskoka sites would be useful to validate the prognostic outcome of the model. Coupling the reaction network to a $3 \mathrm{D}$ flow model would further provide a more complete description of the plume dynamics, especially when considering continued transport at larger distances away from the source.

Model runs with variable aquifer sorption capacities and effluent compositions result in a range of N:P ratios of the discharging groundwater, which varies by up to four orders of magnitude. In aquifers with a low sorption capacity $\left(<0.2 \mathrm{w} / \mathrm{w} \mathrm{Fe}(\mathrm{OH})_{3}\right)$, the extent of plume attenuation over a distance of $20 \mathrm{~m}$ is very limited. It follows that the standard setback distance between infiltration beds and water bodies could be inadequate in some cases. If an $\mathrm{N}: \mathrm{P}$ ratio of $16: 1$, the Redfield ratio, is assumed to be the threshold that determines the limiting nutrient, the discharge of groundwater with a lower N:P ratio, characteristic of aquifers with a low sorption capacity and a low effluent N:P ratio, could potentially drive P-limited systems to N-limitation.

\section{Acknowledgements}

We would like to thank three anonymous reviewers and the Editor, E.O. Frind, for their valuable comments which helped improve the manuscript. This study has been financially supported by the Royal Netherlands Academy of Arts and Sciences (KNAW Fellowship to CPS) and the Netherlands Organisation for Scientific Research (NWO-Pioneer Grant to PVC and NWO-Open Call Grant no 813.02.008 to PR).

\section{References}

Aguilera, D.R., Jourabchi, P., Spiteri, C., Regnier, P., 2005. A knowledge-based reactive transport approach for the simulation of biogeochemical dynamics in earth systems. Geochemistry, Geophysics and Geosystems 6, Q07012. doi:10.1029/2004GC000899.

Anderson, D.M., Glibert, P.M., Burkholfer, J.M., 2002. Harmful algal blooms and eutrophication: nutrient sources, composition and consequences. Estuaries 25 (4b), 704-726.

Appelo, C.A.J., Postma, D., 1996. Geochemistry, Groundwater and Pollution. A.A. Balkema, Rotterdam.

Baker, M.J., Blowes, D.W., Ptacek, C.J., 1998. Laboratory development of permeable reactive mixtures for the removal of phosphorus from onsite wastewater disposal systems. Environmental Science and Technology 32 (15), $2308-2316$.

Barrow, N.J., 1985. Reactions of anions and cations with variable charge soils. Advances in Agronomy 38, $183-230$.

Bohn, H.L., McNeal, B.L., O’Connor, G.A., 1985. Soil Chemistry. John Wiley and Sons, New York. 341 pp.

Canavan, R.W., Slomp, C.P., Jourabchi, P., Van Cappellen, P., Lavermann, A.M., Van den Berg, G.A., 2006. Organic matter mineralization in sediment of a coastal freshwater lake and response to salinization. Geochimica et Cosmochimica Acta 70 (11), 2836-2855.

Cirpka, O.A., Frind, E.O., Helmig, R., 1999. Numerical simulation of biodegradation controlled by transverse mixing. Journal of Contaminant Hydrology 40, 159-182.

Cole, C.V., Olsen, S.R., Scott, C.O., 1953. The nature of phosphate sorption by calcium carbonate. Soil Science Society of America Proceedings 17, 352-356. 
Corbett, D.R., Kump, L., Dillon, K., Burnett, W., Chanton, J., 2000. Fate of wastewater-borne nutrients under low discharge conditions in the subsurface of the Florida Keys, USA. Marine Chemistry 69 (1-2), 99-115.

Corbett, D.R., Dillon, K., Burnett, W., Schaefer, G., 2002. The spatial variability of nitrogen and phosphorus concentration in a sand aquifer influenced by onsite sewage treatment and disposal systems: a case study on St., George Island, Florida. Environmental Pollution 117 (2), 337-345.

Dillon, P.J., Rigler, F.H., 1974. The phosphorus-chlorophyll relationship in lakes. Limnology and Oceanography 19 , $767-773$.

Freeman, J.S., Rowell, D.L., 1981. The adsorption and precipitation of phosphate onto calcite. Journal of Soil Science 32 , $75-84$.

Frind, E.O., Duynisveld, W.H.M., Strebel, O., Boettcher, J., 1990. Modelling of multi-component transport with microbial transformation in groundwater: the Fuhrberg Case. Water Resources Research 26 (8), 1707-1719.

Frossard, E., Brossard, M., Hedley, M.J., Metherell, A., 1995. Reactions controlling the cycling of P in soils. In: Tiessen, H. (Ed.), Phosphorus in the Global Environment. John Wiley \& Sons Ltd., pp. 107-138.

Griggs, E.M., Kump, L.R., Böhlke, J.K., 2003. The fate of wastewater-derived nitrate in the subsurface of the Florida Keys: Key Colony Beach, Florida. Estuarine, Coastal and Shelf Science 58 (3), 517-539.

Gunnars, A., Blomqvist, S., Johansson, P., Andersson, C., 2002. Formation of Fe(III) oxyhydroxide colloids in freshwater and brackish seawater, with incorporation of phosphate and calcium. Geochimica et Cosmochimica Acta 66 (5), $745-758$.

Harman, J., Robertson, W.D., Cherry, J.A., Zanini, L., 1996. Impacts on a sand aquifer from an old septic system: nitrate and phosphate. Groundwater 34, 1105-1114.

House, W.A., Donaldson, L., 1986. Adsorption and coprecipitation of phosphate on calcite. Journal of Colloid and Interface Science 112 (2), 309-324.

Hunter, K.S., Wang, Y., Van Cappellen, P., 1998. Kinetic modeling of microbially-driven redox chemistry of subsurface environments: coupling transport, microbial metabolism and geochemistry. Journal of Hydrology 209, 53-80.

Inskeep, W.P., Silvertooth, J.C., 1988. Kinetics of hydroxyapatite precipitation at pH 7.4 to 8.4. Geochimica et Cosmochimica Acta 52 (7), 1883-1893.

Isenbeck-Schröter, M., Döring, U., Möller, A., Schröter, J., Matthe, G., 1993. Experimental approach and simulation of the retention processes limiting orthophosphate transport in groundwater. Journal of Contaminant Hydrology 14, $143-161$.

Krom, M.D., Berner, R.A., 1980. Adsorption of phosphate in anoxic marine sediments. Limnology and oceanography 25 (5), 797-806.

Kuo, S., Lotse, E.G., 1972. Kinetics of phosphate adsorption by calcium carbonate and Ca-kaolinite. Soil Science Society of America Proceedings 36, 725-729.

MacQuarrie, K.T.B., Sudicky, E.A., 2001. Multicomponent simulation of wastewater-derived nitrogen and carbon in shallow unconfined aquifers I. Model formulation and performance. Journal of Contaminant Hydrology 47 (1), 53-84.

MacQuarrie, K.T.B., Sudicky, E.A., Robertson, W.D., 2001. Multicomponent simulation of wastewater-derived nitrogen and carbon in shallow unconfined aquifers II. Model application to a field site. Journal of Contaminant Hydrology 47, $85-104$.

Millero, F.J., Huang, F., Zhu, X., Lui, X., Zhang, J.-Z., 2001. Adsorption and desorption of phosphate on calcite and aragonite in seawater. Aquatic Geochemistry 7, 33-56.

Mikutta, C., Lang, F., Kaupenjohann, M., 2006. Citrate impairs the micropore diffusion of phosphate into pure and Ccoated goethite. Geochimica et Cosmochimica Acta 70 (3), 595-607.

Molz, F.J., Widdowson, M.A., 1988. Internal inconsistencies in dispersion-dominated models that incorporate chemical and microbial kinetics. Water Resources Research 24, 615-619.

Nriagu, J.O., Dell, C.I., 1974. Diagenetic formation of iron phosphates in recent lake sediments. American Mineralogist 59, 934-946.

Nriagu, J.O., Moore, P.B., 1984. Phosphate Minerals. Springer-Verlag, Berlin. 442 pp.

Parfitt, R.L., 1978. Anion adsorption by soils and soil materials. Advances in Agronomy 30, 1-49.

Parfitt, R.L., 1989. Phosphate reactions with natural allophane, ferrihydrate and goethite. Journal of Soil Science 40, $359-369$.

Parkhurst, D.L., Stollenwerk, K.G., Colman, J.A., 2003. Reactive-transport simulation of phosphorus in the sewage plume at Massachusetts military reservation, Cape Cod, Massachusetts. U. S. Geological Survey Toxic Substance Hydrology Program, Northborough, MA.

Postma, D., Boesen, C., Kristiansen, H., Larsen, F., 1991. Nitrate reduction in an unconfined sandy aquifer: water chemistry, reduction processes and geochemical modeling. Water Resources Research 27, 2027-2045.

Ptacek, C.J., 1998. Geochemistry of a septic-system plume in a coastal barrier bar, Point Pelee, Ontario, Canada. Journal of Contaminant Hydrology 33 (3-4), 293-312. 
Regnier, P., O’Kane, J.P., Steefel, C.I., Vanderborght, J.P., 2002. Modeling complex multi-component reactive-transport systems: towards a simulation environment based on the concept of a Knowledge Base. Applied Mathematical Modelling 26 (9), 913-927.

Regnier, P., Jourabchi, P., Slomp, C.P., 2003. Reactive-transport modeling as a technique for understanding coupled biogeochemical processes in surface and subsurface environments. Netherlands Journal of Geosciences 82, 5-18.

Robertson, W.D., 1995. Development of steady-state phosphate concentrations in septic system plumes. Journal of Contaminant Hydrology 19 (4), 289-305.

Robertson, W.D., 2003. Enhanced attenuation of septic system phosphate in noncalcareous sediments. Ground Water 40 (1), 48-56.

Robertson, W.D., Harman, J., 1999. Phosphate plume persistence at two decommissioned septic system sites. Ground Water 37, 228-236.

Robertson, W.D., Cherry, J.A., Sudicky, E.A., 1991. Ground-water contamination from two small septic systems on sand aquifers. Ground Water 29, 82-92.

Robertson, W.D., Schiff, S.L., Ptacek, C.J., 1998. Review of phosphate mobility and persistence in 10 septic system plumes. Ground Water 36 (6), 1000-1010.

Sayre, I.M., 1988. International standards for drinking water. Journal American Water Works Association 80, 53-60.

Schindler, D.W., 1977. Evolution of phosphorus limitation in lakes. Science 195, 260-262.

Shutter, S.B., Sudicky, E.A., Robertson, W.D., 1994. Chemical fate and transport in a domestic septic system: application of a variably-saturated model for chemical movement. Environmental Toxicology and Chemistry 13, 223-231.

Slomp, C.P., Van Cappellen, P., 2004. Nutrient inputs to the coastal ocean through submarine groundwater discharge: controls and potential impact. Journal of Hydrology 295, 64-86.

Slomp, C.P., Van der Gaast, S.J., Van Raaphorst, W., 1996. Phosphorus binding by poorly crystalline iron oxides in North Sea sediments. Marine Chemistry 52, 55-73.

Slomp, C.P., Malschaert, J.F.P., Van Raaphorst, W., 1998. The role of adsorption in sediment-water exchange of phosphate in North Sea continental margin sediments. Limnology and Oceanography 43 (5), 832-846.

Stollenwerk, K.G., 1996. Simulation of phosphate transport in sewage-contaminated groundwater, Cape Cod, Massachusetts. Applied Geochemistry 11, 317-324.

Stumm, W., Morgan, J., 1981. Aquatic Chemistry: an introduction emphasizing chemical equilibria in natural water. John Wiley \& Sons. 780 pp.

Torrent, J., Schwertmann, U., Barrón, V., 1992. Fast and slow phosphate sorption by goethite-rich natural materials. Clays and clay minerals $40(1), 14-21$.

Valiela, I., Costa, J., Foreman, K., Teal, J.M., Howes, B., Aubrey, D., 1990. Transport of groundwater-borne nutrients from watersheds and their effects on coastal waters. Biogeochemistry 10, 177-197.

Van Cappellen, P., Wang, Y., 1995. Metal cycling in surface sediments: modelling the interplay of transport and reaction. In: Allen, H.E. (Ed.), Metal Contaminated Sediments. Ann Arbor Press, Chelsea, Michigan, pp. 21-62.

Van Cappellen, P., Wang, Y.F., 1996. Cycling of iron and manganese in surface sediments: a general theory for the coupled transport and reaction of carbon, oxygen, nitrogen, sulfur, iron, and manganese. American Journal of Science 296 (3), $197-243$.

Van Raaphorst, W., Malschaert, J.F.P., 1996. Ammonium adsorption in superficial North Sea sediments. Continental Shelf Research 16 (11), 1415-1435.

Van Riemsdijk, W.H., Boumans, L.J.M., De Haan, F.A.M., 1984. Phosphate sorption by soils: I. A model for phosphate reaction with metal-oxides in soils. Soil Science Society of America Journal 48 (3), 537-541.

Weiskel, P.K., Howes, B.L., 1992. Differential transport of sewage-derived nitrogen and phosphorus through coastal watershed. Environmental Science and Technology 26, 352-360.

Westrich, J.T., Berner, R.A., 1984. The role of sedimentary organic matter in bacterial sulfate reduction: the G model tested. Limnology and Oceanography 29 (2), 236-249.

Wilhelm, S.R., Schiff, S.L., Cherry, J.A., 1994a. Biogeochemical evolution of domestic waste water in septic systems: 1. Conceptual model. Ground Water 32 (6), 905-916.

Wilhelm, S.R., Schiff, S.L., Cherry, J.A., 1994b. Chemical fate and transport in a domestic septic system: unsaturated and saturated zone geochemistry. Environmental Toxicology and Chemistry 13 (2), 193-203.

Wilhelm, S.R., Schiff, S.L., Cherry, J.A., 1996. Biogeochemical evolution of domestic waste water in septic systems: 2. Application of conceptual model in sandy aquifers. Ground Water 34 (5), 853-864.

Zanini, L., Robertson, W.D., Ptacek, C.J., Schiff, S.L., Mayer, T., 1998. Phosphorus characterization in sediments impacted by septic effluent at four sites in central Canada. Journal of Contaminant Hydrology 33 (3-4), 405-429. 